\title{
The Persistent Contributions of RNA to Eukaryotic Gen(om)e Architecture and Cellular Function
}

\author{
Jürgen Brosius \\ Institute of Experimental Pathology (ZMBE), University of Münster, D-48149 Münster, Germany \\ Correspondence: RNA.world@uni-muenster.de
}

Currently, the best scenario for earliest forms of life is based on RNA molecules as they have the proven ability to catalyze enzymatic reactions and harbor genetic information. Evolutionary principles valid today become apparent in such models already. Furthermore, many features of eukaryotic genome architecture might have their origins in an RNA or RNA/ protein (RNP) world, including the onset of a further transition, when DNA replaced RNA as the genetic bookkeeper of the cell. Chromosome maintenance, splicing, and regulatory function via RNA may be deeply rooted in the RNA/RNP worlds. Mostly in eukaryotes, conversion from RNA to DNA is still ongoing, which greatly impacts the plasticity of extant genomes. Raw material for novel genes encoding protein or RNA, or parts of genes including regulatory elements that selection can act on, continues to enter the evolutionary lottery.

Everything has been said already, but not yet by everyone.

-Karl Valentin

Sturgeon's Revelation: Ninety percent of science fiction is crud, but then, ninety percent of everything is crud.

$$
\text { - Theodore Sturgeon }
$$

They think that intelligence is about noticing things that are relevant (detecting patterns); in a complex world, intelligence consists in ignoring things that are irrelevant (avoiding false patterns).

—Nassim Nicholas Taleb (Taleb 2010)

O all extant cellular macromolecules, RNA is the most ancient, persisting as much as 4 $\times 10^{9}$ years in our planet's life-forms. The ability to combine genotype with phenotype such as catalytic activity (Noller and Chaires 1972;
Kruger et al. 1982; Guerrier-Takada et al. 1983; Noller et al. 1992) leveled a major hurdle in understanding the origin of life. The salient discoveries eliminated the virtually impossible prerequisite for two to three different classes of macromolecules to converge as an evolving unit. At the same time, RNA provides a required continuity in the path of evolution (Yarus 2011) during various genetic takeovers or evolutionary transitions (Cairns-Smith 1982; Szathmáry and Smith 1995). In a remarkably insightful article dating back half a century, Alex Rich foresaw much of what now is becoming mainstream, for example, that RNA was ancestral to protein and DNA (Rich 1962). This landmark publication received little attention over the years; even early proponents of an RNA world

Editors: Patrick J. Keeling and Eugene V. Koonin

Additional Perspectives on The Origin and Evolution of Eukaryotes available at www.cshperspectives.org

Copyright (C) 2014 Cold Spring Harbor Laboratory Press; all rights reserved; doi: 10.1101/cshperspect.a016089

Cite this article as Cold Spring Harb Perspect Biol 2014;6:a016089 
did not refer to this article (Woese 1967; Crick 1968; Orgel 1968; Gilbert 1986), although at least one of the investigators must have had knowledge about the article, as it was cited in a different context concerning the stereochemical possibility of six distinct base pairs (Crick 1968). The origin of the DNA genome from RNA and that "DNA may be regarded as a derivative molecule which has evolved in the form that it only carries out part of the primitive nucleic acid function" is another correct prediction (Rich 1962). Furthermore, the investigator presaged mechanisms such as antisense RNA control of gene expression, short interfering RNAs (siRNAs), and perhaps microRNAs (miRNAs): "If both strands are active, then the DNA would produce two RNA strands which are complementary to each other. Only one of these might be active in protein synthesis, and the other strand might be a component of the control or regulatory signal" (Rich 1962).

In this article, I shall present the rise and persistence of RNA from the dawn of an RNA world and discuss current evolutionary principles already apparent in an RNA world. In comparison to Archaea and Bacteria, the eukaryotic genome is a better vantage point, as archaeal and bacterial genomes are more derived and, thus, lost many of the RNA signatures that eukaryotes still show. It is likely that eukaryotic DNA genomes not only kept much more of their RNA/ RNP world heritage than previously anticipated, but also continue to evolve novel RNAs in various functional roles.

\section{WHEN DOES LIFE BEGIN?}

An excellent treatise of possible scenarios leading to and continuing in an RNA world to the last universal common ancestor (LUCA) is available (Atkins et al. 2011). Can the beginning of life be defined along the transitions from physicochemical to biological reactions? Like almost everything in biology, clear boundaries are difficult to demarcate and thus the definition of the first life-form rather occupies a bandwidth on a continuum. One of several possible thresholds to consider would be the fortuitous generation of one or two molecules that could replicate themselves or each other. Should the threshold be set at the transition when the molecules involved could change during replication and the variants are subjected to selection-the initial Darwinian ancestor (IDA) (Szathmáry 2006; Yarus 2011)? The first selfreplicating macromolecules must not necessarily have been RNA. Derivatives of RNA, especially with altered backbones, have been suggested as predecessors of RNA owing to more favorable chemistries/stabilities for spontaneous generation and persistence of oligomerization at the presumed planetary conditions (Joyce et al. 1987; Schöning et al. 2000; Zhang et al. 2005; Powner et al. 2009; Robertson and Joyce 2012; Neveu et al. 2013).

An interesting question is, if it is that "simple," why did life not evolve multiple times? There are a number of explanations. The early environment of the planet with conditions favoring the necessary chemical reactions differed from the more temperate conditions now (Robertson and Joyce 2012). Perhaps life did evolve before LUCA numerous times independently, but the descendants of LUCA are the only survivors. Perhaps primitive forms of life, for example, in the form of IDAs, still do arise, but we are not aware of them, in part, because we have not searched for such simple and different lifeforms. Another reason is that a nascent form of life would easily be outcompeted by the established ones, as the latter had a great chronological advantage adapting to current conditions. New forms of life might have a chance only if their metabolism is sufficiently different and, thus, not useful prey to LUCA-related life-forms or if they happened to evolve in an unoccupied niche so as not to succumb to immediate predation by the fitter "incumbents."

\section{RETRACING THE PATH}

In any event, by applying in vitro synthesis and selection procedures (Ellington and Szostak

\footnotetext{
${ }^{1}$ An afterthought worthy of note is the dichotomy with respect to life's fragility considering individuals, even species versus the resilience of life as a whole, over an $\sim 4$-billionyear timescale.
} 
1990; Tuerk and Gold 1990; Gold et al. 2012), several laboratories are making great strides toward generating RNA molecules with the ability to self-replicate (Doudna and Szostak 1989; Johnston et al. 2001; Zaher and Unrau 2007; Lincoln and Joyce 2009; Shechner et al. 2009; Wochner et al. 2011; Attwater et al. 2013; Mast et al. 2013), although these RNA polymerase ribozymes still fail to completely self-replicate (Deamer 2005). Cooperation of two or more RNA enzymes in hypercycles (Eigen and Schuster 1977) may be a solution to this problem (Vaidya et al. 2012) (see also below).

Once a self-replicating ribozyme (mono- or multimeric) arose with the further potential to evolve into a replicator not restricted to only self-copy but to copy other RNA templates as well, a prerequisite for a metabolically self-sufficient RNA conglomerate, further challenges are apparent. First, the replicator indiscriminately copying any "junk RNA" in the mix hardly would be able to persist. Second, if further RNA molecules would arise by copying with errors-just like in extant organisms, new genes still arise by duplication and variation-to eventually take over metabolic functions other than replication (e.g., activated compounds, including nucleotides), these associations would be fleeting, at best, because of diffusion.

\section{SEQUESTRA, AMPLIFICA, DIVIDE ET IMPERA!}

A compartmentalization of cellular constituents in droplets, as suggested by Carl Woese (1979), stabilized by simple fatty acids (Szostak et al. 2001) was an early evolutionary transition (Maynard Smith and Szathmáry 1995) crucial for the continuation of life. Recent experiments showed that such bilayered partitions were sufficiently permeable for uptake of small molecules from the environment and copying nucleic acids in such vesicles is possible (Sacerdote and Szostak 2005; Mansy et al. 2008; Adamala and Szostak 2013). This sequestration was a prerequisite for cellular life and evolution as we know it today, with many evolutionary principles in place already (Brosius 2003c). Vesicles could grow along with their RNA contents, di-
RNA and Eukaryotic Gene/Genome Architecture

vide, fuse while shuffling their contents and divide again, in other words, performing sexual acts. Another "forecast" of the mechanisms generating genomic diversity would be recombination not only between cells, but also between different RNA molecules, a mechanism that actually had been observed in a two-component ribozyme system (Lincoln and Joyce 2009). The origin of viruses could date to this early stage of cellular evolution as well. RNA molecules could, perhaps protected by a lipid envelope, move from cell to cell, blurring the line between infection and horizontal transfer.

\section{MOST EVOLUTIONARY PRINCIPLES ARE AT LEAST AS ANCIENT AS THE RNA WORLD}

Lessons from the RNA world apply remarkably well to extant organisms and their genomes. In a primitive RNA cell, conflict and cooperation, selfishness and altruism had to coexist and establish a fine balance. Importantly, the success of individual ribozymes also depended to a large degree on functional interactions with other cellular RNAs (today: gene products), namely, the (genetic) background of the protocell (Brosius 2003c). In contemporary biology and medicine, considerations of interactions of various alleles within the genomic background, as well as individual variability of gene expression levels including complete gene depletions, are beginning to gain wider acceptance (Williams and Nesse 1991; Sibilia and Wagner 1995; Brosius 2003b; Ganten and Nesse 2012; Nesse et al. 2012).

Balances between selfishness and cooperation had to evolve early; this is recently documented by in vitro selection research that revealed in an experiment to generate Tetrahymena group I ribozymes with improved DNA cleavage capability that one of the two RNA aptamers, itself being catalytically inactive, participated in a productive intermolecular interaction with an active ribozyme evolving in parallel, thus, ensuring the survival of both RNAs in the nucleic acid population (Hanczyc and Dorit 1998). Other studies also show that parasites can cause the evolution of further complexity (Takeuchi and Hogeweg 2008). In 
J. Brosius

the case of the bacterially derived $A z o \Delta$ ribozyme, a clonal preparation showed no activity toward the phosphorothioate substrate. Presumably, this sequence alone fails to show a functional fold, but could form an active complex in an intermolecular partnership with other RNA molecules (Hayden et al. 2011). Recently, it was shown that cooperative cycles of replication involving three or four participating RNAs have a selective advantage over selfish replication cycles (Vaidya et al. 2012), as formulated earlier in the hypercycle principle of natural self-organization (Eigen and Schuster 1978 ) and placed into context with extant organisms (Brosius 2003c). The participation of several small RNAs also has the potential to significantly increase the complexity of ribozymes.

\section{CHROMOSOMAL RNA}

The dispensation of essential RNA molecules between daughter cells was initially stochastic, probably facilitated by the availability of sufficient copies of each RNA species in the parent cell, such that each daughter would have a reasonable chance to end up with at least one complete set of RNAs. If initially a few different RNAs were strung together as "mini RNA chromosomes," the advantage would be achievement of a more balanced distribution of RNAs. Perhaps they were distributed and replicated as such, with some of them cut up into functional RNAs, conceivably the birth of RNA processing. Processing signals might have been placed, in part, between the fragments corresponding to mature RNAs, presumably the origin of intergenic or even intronic space (Brosius 2003c). With the advent of templated protein biosynthesis, a major evolutionary transition included co-option of existing functional RNAs as well as longer "chromosomal RNAs" by RNA cutting and pasting to stitch together messenger RNAs (mRNAs) with open and increasingly longer reading frames, which might suggest a very early origin of RNA splicing in a ribonucleoprotein world (RNP world) (Reanney 1974; Darnell and Doolittle 1986). Alternative splicing and other rearrangements would be one of the mechanisms to enhance variation for generating translation products out of a limited repertoire of functional RNAs also doubling as templates for translation (Brosius 2001).

\section{RNA SIGNATURES WRITTEN ALL OVER EXTANT DNA GENOMES}

Linear arrangement of RNA genes, as well as the transition to the RNP world evolving an ancestor of the reverse transcriptase enzyme, happened to constitute a useful precondition for a next major evolutionary transition, namely, the conversion of RNA to DNA, the latter merely serving as bookkeeper (Darnell and Doolittle 1986; Gould 2002). For this and other reasons, the central dogma of biology could be revisited or supplemented by a different graphic account, both in appreciation of the major significance of RNA in the cell and the chronological order of the major transitions (Fig. 1) (Maizels and Weiner 1987; Brosius 2003a; Cech 2012). Remarkably, the process of reverse transcription of any RNA (Brosius 1999b) and more or less random integration into DNA genomes still persists and contributes much to their landscapes in a number of ways. The modular arrangement of functional with nonfunctional DNA and its plasticity in extant eukaryotic genomes might be a vestige of early evolutionary transitions (Brosius 2009).

Reverse transcriptase not only played an important role in generating the DNA genome but continues to be essential for chromosome maintenance via the action of telomerase. The extant enzyme synthesizes telomeres that serve as protective caps of chromosome ends, thus counteracting their shortening during replication cycles. Telomerase is a complex between RNA and protein in which the RNA serves as template and protein as reverse transcriptase (Greider and Blackburn 1989; Blackburn et al. 2006; Blackburn and Collins 2011). Group II introns, when transcribed as RNA are self-splicing with the activity residing on the RNA at high salt conditions in vitro (van der Veen et al. 1986). For in vivo activity and integration at new genomic sites in a process termed reverse splicing, a reverse transcriptase encoded in the intron 
RNA and Eukaryotic Gene/Genome Architecture

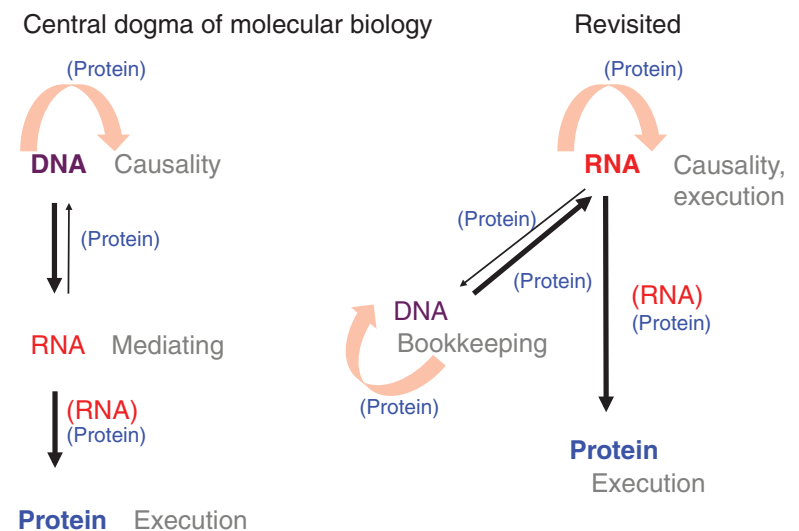

Figure 1. Alternative to the central dogma of molecular biology. The left part depicts the original central dogma of molecular biology with several adjustments incorporated, for example, the discovery of reverse transcription (thin upward arrow) (Crick 1958, 1970). The grouping on the right better reflects the evolutionary transitions and primacy of RNA. RNA could be replicated directly (semicircular arrow), albeit in extant organisms (e.g., plants, viruses) only with the catalytic activity of protein (RNA-dependent RNA polymerase). In this scheme, catalysis is indicated by (RNA) and or (protein) in parentheses. The major significance of RNAs for peptidyl transferase activity during translation (Noller 2012) is represented by the larger font for (RNA) compared to (Protein). Execution includes structural, catalytic, and regulatory tasks in the cell. The evolutionary developments underscore Stephen Jay Gould's view that DNA merely is the agent of bookkeeping (Gould 2002). RNAs used to be bookkeepers as well, but remained agents of causality (Brosius 2005a).

is necessary (Lambowitz and Zimmerly 2011). The ribozyme has been proposed to be ancestral to non-LTR (long terminal repeat) retroposons as well as the spliceosome attributable to similarities of their reverse transcriptase and some small nuclear RNA (snRNA) components of the spliceosome, including aspects of the splice mechanism itself, respectively (Xiong and Eickbush 1990; Guthrie 1991; Sharp 1991; Fica et al. 2013). The rapid spread of introns in eukaryotes has been ascribed to group II introns after they were imported by endosymbionts (CavalierSmith 1991), perhaps necessitating the separation of slow mRNA production in the nucleus from the fast translation in the cytoplasm, one of the hallmarks of the eukaryotic cell (Martin and Koonin 2006). ${ }^{2}$

\footnotetext{
${ }^{2}$ As mentioned above, some of the intron gain could date back as far as the RNA world, or at least back to LUCA, because type II introns are present in bacteria (Ferat and Michel 1993) and in the more derived bacterial and archaeal genomes, introns could have been lost (Poole et al. 1999). Massive intron loss would be reminiscent of a relatively recent purge of most introns in the yeast $S$. cerevisiae via retroposition (Fink 1987).
}

Importantly, the process of continuously converting RNA to DNA and its genomic integration has the potential to grossly inflate genomes with neutrally evolving material and, in conjunction with larger deletion of segments by recombination, leads to a high turnover rate of sequences on an evolutionary time scale, once more calling into question the ENCODE claim that $\sim 80 \%$ of the human genome is functional (Doolittle 2013; Graur et al. 2013; Niu and Jiang 2013). Generally, specific retroposons ${ }^{3}$ become active in certain lineages, and reverse transcripts from one or several master gene transcripts, such as LINEs (long interspersed elements), autonomous as they harbor gene encoding the retroposition machinery such as reverse transcriptase and nonautonomous SINEs (short interspersed elements), such as Alu or B1 elements. Nonautonomous retroposons rely on the machinery of the autonomous retroposons.

\footnotetext{
${ }^{3} \mathrm{~A}$ general term for retroposed sequences as well as DNA transposons is "transposable" elements (TEs). However, because following retroposition most elements are not able to transpose any longer attributable to truncations, lack of transcription, etc., the writer prefers "transposed" elements.
} 
J. Brosius

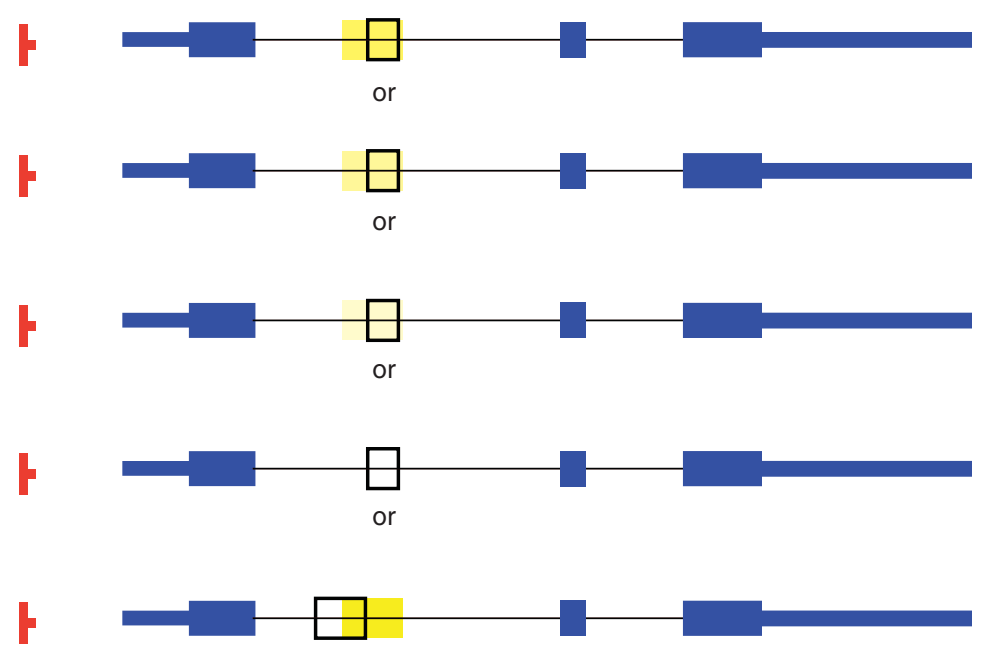

Figure 2. Exaptation of a new gene module at any stage of transposed element (TE) deterioration. In this example, a SINE, such as Alu, B1, identifier (ID), or mammalian-wide interspersed repeat (MIR), is retroposed into the first intron of a gene (introns depicted by thin black lines and the SINE as wide yellow bar). The gene harbors three exons (in blue). Open reading frames (ORFs) are shown as wide bars, whereas the $5^{\prime}$-UTR (untranslated region) and $3^{\prime}$-UTR are shown as narrower blue bars, in the terminal exons, respectively. The transcription promoter is depicted in red. The four top representations indicate the gradual decay of the SINE element by continuous mutation fading from yellow to white; thus, blending into the other anonymous sequence of the intron. At any of those stages, part of the TE can be exapted as novel exon (framed in black). Sometimes part of a discernible TE and adjacent anonymous intron can be exapted as novel gene module (bottom).

Most retrocopies are not active as they are transcriptionally silent because of the lack of internal (e.g., truncation of LINEs) or external promoters in SINEs. Intact and transcribed master genes can spawn, over a few tens or hundreds of million years, more than one million copies, as is the case for Alu elements (Weiner 2006). With a few exceptions (see below), there is no selective pressure on such elements and, accordingly, they deviate over time from the consensus sequence. The human genome has been estimated to contain $\sim 43 \%$ retroposons, a relatively small amount of DNA transposons $(\sim 3 \%)$, and as little as $5 \%$ conserved sequences (LindbladToh et al. 2011; Ward and Kellis 2012) that potentially have function (Fig. 2). ${ }^{4}$ As argued before, conversion of RNA to DNA is an ancient process and it has been suggested that most DNA in the human genome has been derived

${ }^{4}$ See discussion points below that absence or low levels of conservation must not necessarily rule out function and vice versa. by a virtually unabated bombardment of retroposons (Brosius 1999a). Over time, these elements are blurring into oblivion as randomized sequences by incessant changes, such as point mutations and small indels. Recently, it was confirmed by more sensitive computational strategies involving P-clouds, that almost 70\% of the human genome may harbor repetitive elements (de Koning et al. 2011). Extrapolating back to or forward from the origin of RNA $\rightarrow$ DNA genome transition, there is no reason why this figure, except for the generally lesser contributions of DNA transposons, should not approach almost 100\% (Brosius 1999a). The fact that essential sequences are interspersed with nonessential sequences as landing pads for transposed elements lessening their detrimental impact genome-wide could be chalked up to the ENCODE project (Bernstein et al. 2012), as well as adherents to intelligent design, creationists, and the like as "functional," which would cleanse our species from the blemish of living with $\sim 80 \%-90 \%$ junk DNA in our ge- 
nomes (Doolittle 2013; Graur et al. 2013; Niu and Jiang 2013).

\section{YESTERDAY'S JUNK COULD BECOME TOMORROW'S NOVEL GENE MODULE, IF ONLY TEMPORARILY SO}

The lack of purifying selection concerning nonharmful TEs, including mRNA-derived retrocopies, should not divert from the fact that, occasionally, such sequences can be exapted as genetic novelties (Brosius 1991; Brosius and Gould 1992). Gene duplication as a means of generating novel genes has been realized for a long time (Haldane 1933; Muller 1935; Bridges 1936; Lewis 1951; Stephens 1951; Nei 1969). Gradual change from a duplicated gene, via those encoding isoforms, up to the acquisition of novel functions including subfunctionalization (Lynch and Force 2000) is now well documented (Roth et al. 2007; Kaessmann 2010; Chen et al. 2013). Gene amplification can occur via segmental duplication (Bailey and Eichler 2006) or retroposition (Brosius 1999a; Babushok et al. 2007) with a lower "success rate" for the latter. Retroposition of a copy of the mature mRNA requires the fortuitous presence of a promoter element upstream, which, as a potential benefit, could immediately alter regulation of the retrogene in comparison to the parent gene (Brosius 1999b). Genes, chiefly those encoded by endogenous retroviruses, were independently exapted or domesticated numerous times into novel functions, some of them are meanwhile essential for procreation or survival (Volff 2006, 2009). Also, DNA copies of nonretroviral RNA genomes, or parts thereof, can be integrated into genomes (Koonin 2010). In fungi, exaptations of such genes were reported (Taylor and Bruenn 2009), underscoring once more the notion that any RNA can be a template for the retroposition machinery (Brosius 1999b).

Can novel genes arise de novo from previously gene-free neutrally evolving genome regions? Despite some false positives (Monte et al. 1997; Kriegs et al. 2005), recruitment of entire protein-coding genes out of neutrally evolving sequences does occur (Long et al. 2003, 2013; Heinen et al. 2009; Kaessmann 2010; Carvunis et al. 2012; Murphy and McLysaght 2012; Neme and Tautz 2013). Recently, it has been emphasized that many long non-protein-coding RNAs originated from TEs (Kapusta et al. 2013). This RNA class is discussed in more detail below. In any event, it is much more common that novel gene modules are being added to existing genes. Such co-opted or exapted modules can be derived from inter- or intragenic space and constitute novel protein-coding exons and regulatory regions such as promoters and enhancers (Brosius 2005b, 2009; Baertsch et al. 2008; Rebollo et al. 2012). ${ }^{5}$ A prominent case is the exonization of parts of Alu elements, usually as alternatively spliced exons (Makalowski et al. 1994; Nekrutenko and Li 2001; Sorek et al. 2002; Lev-Maor et al. 2003; Krull et al. 2005; Shen et al. 2011). Many such events are, over evolutionary time, not stable. That is, they persist for a certain time if they are not or only slightly detrimental, especially when the novel splice product only constitutes a fraction of the functional RNA. Should, over time, the novel splice variant happen to become beneficial, it will be under purifying selection and, by point mutations in and around splice signals, its ratio, in comparison to the canonical splice form, might change in its favor. In a phylogenetic study on primates, it has been shown that such exons derived from Alu elements are lost at a high rate in the trial and error mode, typical for the evolution of novelties (Krull et al. 2005). A similar study involving all mammals and the older MIRs revealed that many of the events were already fixed and currently are under negative selection. The study also shows, in the case of a relatively recent exonization of an ancient MIR element, that exaptation can occur at any stage of TE decay (Fig. 3), and consequently also with any nondescript randomized DNA (Krull et al. 2007). Recently, a mechanism was described by which a snoRNA

\footnotetext{
${ }^{5}$ Even modules that reduce or destroy the activity of a targeted gene and/or its product can be beneficial to the host. $X m r k$ is an epidermal growth factor receptor-related oncogene in certain Xiphophorus fish hybrids and, when overexpressed, leads to melanoma. Insertion of an autonomous non-LTR retrotransposon disrupted and deactivated Xmrk As a consequence, the individuals harboring this insertion do not develop tumors (Schartl et al. 1999).
} 

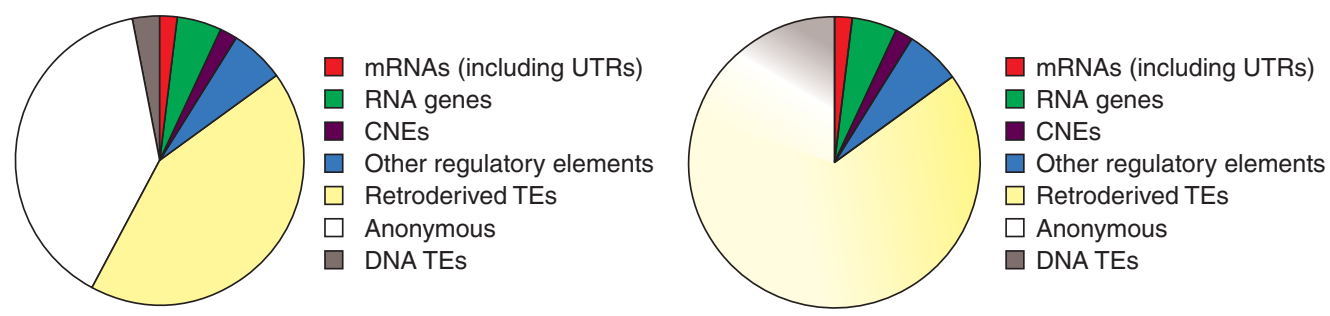

Figure 3. The functional versus nonfunctional human genome. The pies represent the various segments of the genome applying more conservative estimates. mRNAs $(\sim 1.3 \%$ accounting for ORFs $)$ including their $5^{\prime}-$ and $3^{\prime}$-UTRs $(\sim 0.8 \%)$ occupy slightly $>2 \%$ of the human genome. All other RNAs (non-protein-coding RNAs) are estimated to cover about $5 \%$ (green), maximally $10 \%$. This figure is under debate. Likewise, there is a conservative estimate for regulatory elements of $\sim 8 \%$. Other sources argue up to 20\% (Bernstein et al. 2012; Shen et al. 2012). Because conserved non-protein-coding DNA elements (CNEs, $\sim 2 \%$, purple) often encode cis-regulatory elements (Hiller et al. 2012), the other regulatory elements are shown as 6\% only (blue). TEs derived from RNA intermediates contribute $\sim 43 \%$ (yellow) and DNA transposons only 3\% (brown). The remainder (39\%) corresponds to anonymous, scrambled sequences (white). The estimated 26\% introns (Bernstein et al. 2012) occupy mostly the yellow and white segments; intronic regulatory elements and encoded RNAs (e.g., snoRNAs, miRNAs) are accounted for in the respective segments. The pie on the right is identical, except that the retroposons (yellow) and, to a lesser extent, the DNA transposons (brown), blend into the anonymous sequence (white) to reflect TE ancestry of the nondescript sequences as well.

(small nucleolar RNA) extended its RNA-coding region by alternative processing of its $3^{\prime}$ end by introducing a single-point mutation near the site important for processing, generating both the canonical snoRNA and an extended variant (Mo et al. 2013). This event, detected in a cluster of rat Snord115 snoRNA genes in the imprinted Prader-Willi syndrome locus, but not in mouse, must be relatively recent. The additional gene product, L-Snord115, has most likely not yet acquired a function. The odds are that this snoRNA variant will not survive another dozen or so million years.

\section{ALL WIRED UP ON REWIRING}

Examples for TE contributions to gene expression by providing promoter or enhancer modules have been known for some time and are ample (Jordan et al. 2003; van de Lagemaat et al. 2003; Medstrand et al. 2005). Interestingly, TEs that were conserved at unusually high levels over hundreds of millions of years were reported to act as enhancers (Bejerano et al. 2006; Santangelo et al. 2007; Sasaki et al. 2008; LindbladToh et al. 2011; Lowe and Haussler 2012). Recently, a number of publications proposed that the spreading of copies from active TE classes can lead to rapid rewiring, affecting hundreds of genes whose expression is being altered as a consequence, and is caused by the action of additional transcription factors binding to those enhancers (Wang et al. 2007; Bourque et al. 2008; Feschotte 2008; Xie et al. 2010; Lynch et al. 2011; Rebollo et al. 2012). This might even involve Alu elements in the form of Alu-derived miRNAs or non-miRNAs (Du et al. 2013; Hoffman et al. 2013; Liang and Yeh 2013; Mandal et al. 2013; Spengler et al. 2014).

Nevertheless, caution should be applied for the following reasons:

(1) Four ultraconserved elements were deleted in mice. Although there is no indication that these elements show immediate ancestry to TEs, the lesson equally applies to TE-derived enhancers. In this study, enhancer elements adjacent to genes whose protein-coding exons, when deleted, showed clear phenotypes in mice were chosen for deletion and the elements also were known to function as enhancers. In all four cases, the mice were not only viable and fertile, but also failed to reveal any obvious phenotype among the many parameters tested in the laboratory (Ahituv et al. 2007). Experimentally, it appears to be much easier to obtain a positive expression result with reporter con- 
structs than a phenotype by enhancer ablation (Nelson and Wardle 2013).

(2) Should a newly acquired or activated TE class with "ready-to-use" enhancer activity populate a genome in high numbers, it might not smoothly rewire expression of a set of genes in a functionally viable manner, but simply wreak havoc in a genome by juxtaposition of new enhancers to resident genes. Such eruptions of TEs would be expected to have at least as many detrimental effects than beneficial ones. A less radical scenario would be the following: TEs carry sequences resembling transcription factor binding sites (TFBS) or other regulatory regions that pending minor mutations have the potential to become functional.

(3) Enhancers usually harbor clusters of homotypic or heterotypic TFBS and therefore it is less likely that most TEs are instantly functional. Enhancers usually act in a modular fashion and rather than changing expression patterns, they add a cell-type/tissue or a developmental window to existing expression patterns. After a period of testing ( just as in the case of exonization; see above), this or other modules might get lost (adding or exchanging a few mains, yes; rewiring, hardly). For a recent comprehensive assessment of these problems, see de Souza et al. (2013).

\section{TE FUNCTIONS: TO THE MOON!}

TEs are insertional mutagens and often enough, integration near or into functional modules of the genome is disadvantageous and, for example, can cause disease (Chen et al. 2005; Callinan and Batzer 2006; Iskow et al. 2010; Hancks and Kazazian 2012). Because of affordable highthroughput sequencing technologies, the search for somatic de novo insertions of TEs becomes feasible. Numerous such events could be detected in tumor tissues and cells (Miki et al. 1992; Lee et al. 2012), some of which might be causal. Somatic integration even was proposed to contribute to neuropsychiatric disease, such as schizophrenia (Bundo et al. 2014). Apart from being detrimental or neutral, a minority of events has the potential to turn out beneficial.

TEs of a certain class might harbor not only TFBS, but also numerous other functional se- quences in their consensus sequences, and, perhaps, mainly because these elements are defined by their designation, proposals with highly diverse functions are being published, even involving TEs with very narrow phylogenetic distributions (Allen et al. 2004; Espinoza et al. 2004, 2007; Lunyak et al. 2007; Mariner et al. 2008; Gong and Maquat 2011; Yakovchuk et al. 2011; Carrieri et al. 2012; Jady et al. 2012; Holdt et al. 2013; Ponicsan et al. 2013; Wang et al. 2013). Somatic LINE element integrations even have been implied in the development of the brain (Muotri et al. 2005; Coufal et al. 2009; Faulkner et al. 2009; Singer et al. 2010; Baillie et al. 2011; Upton et al. 2011; Perrat et al. 2013; Reilly et al. 2013). Either TEs are chock full of regulatory motifs and control elements, which can be argued in case of promoters, for example, LTRs (Feuchter and Mager 1990), or it is the fact that TEs are defined and designated nucleic acid sequences (nuons) (Brosius and Gould 1992) and, therefore, receive more attention instead of randomized and anonymous sequences in attempts to investigate their functions. Perhaps one or the other of these exhilarating findings will share the fate of ID repetitive elements and TEs of the SINE class, in a development that unfolded about three decades ago. A lot of excitement was generated by reports that ID elements regulate brain-specific gene expression (Milner et al. 1984; Sutcliffe et al. 1984a,b; McKinnon et al. 1986). Unfortunately, these claims did not stand the test of time (Owens et al. 1985; Sapienza and St-Jacques 1986; Goldman et al. 2014). ${ }^{6}$ For sure, any seemingly insig-

\footnotetext{
${ }^{6}$ Ironically, the presence of a brain-specific RNA (BC1 RNA) with similarity to the consensus sequence of ID elements had been noticed in early publications, but dismissed as byproduct of a functional act of transcription (Sutcliffe et al. 1984a). This activity by RNA polymerase III had been suggested to open the chromatin structure of brain-specific genes to allow transcription by RNA polymerase II (Sutcliffe et al. 1984b). It turned out, however, that BC1 RNA is encoded by a single active gene, is a master gene for the ID repetitive SINEs, and is functional (DeChiara and Brosius 1987; Martignetti and Brosius 1993; Kim et al. 1994; Wang et al. 2002; Lewejohann et al. 2004; Iacoangeli and Tiedge 2013). This perfectly reflects the "Zeitgeist" of the era and is in stark contrast to the current situation in which almost anything that features a ribogroup is being considered functional (see below).
} 
J. Brosius

nificant novelty could have far-reaching consequences for future lineages (Martignetti and Brosius 1993; Kapitonov and Jurka 2005), but in their infancy, the functional significance, if not potential of novelties, is not easy to assess and often might be transitory. And what is true for regulatory elements and protein-coding genes and their exonic modules should also apply to functions of non-protein-coding RNAs.

\section{FUNCTIONAL RNA: ALIVE AND KICKING}

Despite the growing recognition of RNA's functional significance and versatility, as well as its preeminence in the evolution of life, up to $\sim 15$ years ago, most scholars in the life sciences still deemed RNA molecules as fossils or remnants from bygone eras. The most complex cytoplasmic RNA class, messengers between the genetic information on DNA and ribosomes, organelles in which structural and functional macromolecules (proteins) of a cell are being assembled, did not generate much excitement any longer after the genetic code had been cracked (Nirenberg et al. 1965; Söll et al. 1965).

A minority of investigators sensed that the previously known and rather abundant nonprotein-coding RNAs, such as transfer and ribosomal RNAs, were only the tip of the iceberg (Prestayko and Busch 1968; Zieve and Penman 1976; Lerner et al. 1980; Brown and Fournier 1984; Lee et al. 1985; Erdmann and Wolters 1987; Mattick 1994; Brosius 1996) and that even novel functional RNAs could evolve (DeChiara and Brosius 1987; Brosius 1991). The floodgates began to open when sequencing of copy DNA generated from non-mRNA fractions revealed a plethora of novel RNAs and RNA classes including miRNAs (Filipowicz 2000; Huttenhofer et al. 2001; Lagos-Quintana et al. 2001; Couzin 2002). The development of deep and ultradeep sequencing methods for cellular, organ-specific, and whole transcriptomes of organisms greatly accelerated the deluge of data (Wang et al. 2009). The past 15 years have surprised most of the scientific community with the incessant discovery of thousands of novel RNAs, some extending RNA species from already known classes such as snoRNAs, some establishing novel RNA classes (e.g., miRNAs and siRNAs), and some unclassified (Fire et al. 1998; Ambros 2001; Lagos-Quintana et al. 2001; Lau et al. 2001; Moss 2001; Ruvkun 2001; Couzin 2002; Carninci et al. 2005; Derrien et al. 2012; Djebali et al. 2012; Kapranov et al. 2012; Ross et al. 2014). Even extracellular RNAs are receiving renewed attention (Benner 1988; Wu et al. 2002; Dunoyer et al. 2007; Leslie 2013a). Major RNA classes are summarized in Table 1 . $^{7}$

It appears that the mining of novel tiny and small RNAs is reaching a point of deceleration (Saxena and Carninci 2011b) and, as a result, long RNAs are receiving more attention (Jacquier 2009; Ponting et al. 2009; Carninci 2010; Derrien et al. 2012; Hu et al. 2012; St Laurent et al. 2012; Cloutier et al. 2013; Di Ruscio et al. 2013; Geisler and Coller 2013; Kung et al. 2013; Orom and Shiekhattar 2013; Sabin et al. 2013; Ulitsky and Bartel 2013; Fatica and Bozzoni 2014; Yang et al. 2014). Oligonucleotide array sequence analysis, conventional RNA sequencing, and RNA-sequencing technologies (FANTOM) (Carninci et al. 2005; Cheng et al. 2005; Birney et al. 2007; Mercer et al. 2012), even in combination with biocomputation, taking phylogenetic considerations and/or the potential for forming secondary structures into account, mostly come up with at least ten thousand long non-protein-coding RNA candidates (Washietl et al. 2007; Managadze et al. 2013; Necsulea et al. 2014; Nielsen et al. 2014).

\section{DID RNA ENTER BUBBLE TERRITORY?}

The percentage of the human genome that is being transcribed appears to be approaching the maximum asymptotically. A simple explanation is the increased coverage with ultradeep sequencing methods and coverage of any cell type including tumors, many developmental stages, as well as (tumor) cell lines numerous

\footnotetext{
${ }^{7}$ Detailed descriptions of the RNA classes and their (potential) functions can readily be found in reviews and the vast original literature cited therein, for example, Prasanth and Spector 2007; Costa 2010; Aalto and Pasquinelli 2012; Djebali et al. 2012; Kapranov et al. 2012; Dieci et al. 2013; Gomes et al. 2013; Leslie 2013b.
} 
RNA and Eukaryotic Gene/Genome Architecture

Table 1. RNA classification

\begin{tabular}{|c|c|c|}
\hline RNA class & $\begin{array}{l}\text { Approximate } \\
\text { size (nt) }\end{array}$ & Function \\
\hline $\begin{array}{l}\text { Tiny RNAs, }<50 \text { nt } \\
\text { microRNA, miRNA }\end{array}$ & $21-24$ & $\begin{array}{l}\text { Gene regulation, for example, fine-tuning at the } \\
\text { translational level }\end{array}$ \\
\hline Short interfering RNA, siRNA & $20-25$ & RNA interference, defense \\
\hline PIWI-interacting RNA, piRNA & $26-31$ & $\begin{array}{l}\text { Epigenetic and posttranscriptional gene silencing } \\
\text { of TEs }\end{array}$ \\
\hline $\begin{array}{l}\text { Small RNAs, } \sim 50-500 ~ \mathbf{~ t ~} \\
\text { Extracellular RNA, exRNA }\end{array}$ & Wide range & Intercellular communication \\
\hline \multicolumn{3}{|l|}{ Small nuclear RNA (snRNA) } \\
\hline $\begin{array}{l}\text { Spliceosomal RNAs, U1, U2, U4, U5, etc. } \\
\text { RNAs }\end{array}$ & $100-200$ & Splicing of mRNA out of primary transcripts \\
\hline U7 RNA & 50 & $3^{\prime}$ processing of histone mRNA precursors \\
\hline $\begin{array}{l}\text { Ribonuclease P RNA, RNase P RNA or H1 } \\
\text { RNA }\end{array}$ & 340 & tRNA processing \\
\hline 7SK RNA & 330 & Regulation of transcription \\
\hline Y RNA & $90-100$ & DNA replication \\
\hline Telomerase RNA component, TERC & 450 & Maintenance of telomeres \\
\hline Small nucleolar RNA, snoRNA & $60-300$ & Guide RNAs for nucleotide modification \\
\hline C/D box snoRNA & & $2^{\prime} \mathrm{O}$-methylation of the ribose moiety of rRNA \\
\hline H/ACA box snoRNA & & rRNA pseudouridinylation \\
\hline Cajal body-specific RNA, scaRNA & & $\begin{array}{l}\text { Composite } \mathrm{C} / \mathrm{D} \text { and } \mathrm{H} / \mathrm{ACA} \text { guide RNA, } \\
\text { modification of snRNAs }\end{array}$ \\
\hline $\mathrm{U} 3, \mathrm{U} 8, \mathrm{U} 14, \mathrm{U} 17$, and $\mathrm{U} 22$ snoRNAs & & $\begin{array}{l}\text { Regulation of preribosomal RNA ( pre-rRNA) } \\
\text { folding, mediation of correct nucleolytic } \\
\text { processing (maturation) }\end{array}$ \\
\hline "Orphan" snoRNAs & & $\begin{array}{l}\text { Target of modification (if any) and function } \\
\text { unknown, examples are SNORD115 and } \\
\text { SNORD116 in the PWS (Prader-Willi } \\
\text { syndrome) locus }\end{array}$ \\
\hline \multicolumn{3}{|l|}{ Small cytoplasmic RNA, scRNA } \\
\hline $5 \mathrm{~S}$ and $5.8 \mathrm{~S}$ small ribosomal RNAs & 120,150 & Translation \\
\hline Transfer RNAs, tRNAs & $73-94$ & Adapter molecules in translation \\
\hline $\begin{array}{l}\text { Signal recognition particle RNA, 7SL RNA } \\
\text { or SRP RNA }\end{array}$ & 300 & Targets protein to the endoplasmic reticulum \\
\hline Vault RNAs & $90-100$ & $\begin{array}{l}\text { Components of the vault organelle, function not } \\
\text { clear yet }\end{array}$ \\
\hline $\begin{array}{l}\text { Ribonuclease MRP, mitochondrial RNA } \\
\text { processing RNA }\end{array}$ & 290 & $\begin{array}{l}\text { Mitochondrial DNA replication and rRNA } \\
\text { processing in the nucleus }\end{array}$ \\
\hline BC1 RNA & 150 & $\begin{array}{l}\text { Neuronal cytoplasmic RNA (some expression in } \\
\text { testes) in soma, but also transported to } \\
\text { dendrites, possibly involved in regulation of } \\
\text { translation; phylogenetically restricted to } \\
\text { rodents, originated from tRNA retroposition }\end{array}$ \\
\hline BC200 RNA & 200 & $\begin{array}{l}\text { Neuronal cytoplasmic RNA (some expression in } \\
\text { testes) in soma, but also transported to } \\
\text { dendrites, possibly involved in regulation of } \\
\text { translation; phylogenetically restricted to } \\
\text { anthropoid primates; not homologous to } \mathrm{BC} 1 \\
\text { RNA, originated from a monomeric Alu element }\end{array}$ \\
\hline
\end{tabular}

Continued 
J. Brosius

Table 1. Continued

\begin{tabular}{|c|c|c|}
\hline RNA class & $\begin{array}{l}\text { Approximate } \\
\text { size }(\mathrm{nt})\end{array}$ & Function \\
\hline \multicolumn{3}{|l|}{ Long RNAs, > $>500 \mathrm{nt}$} \\
\hline $18 \mathrm{~S}$ and $28 \mathrm{~S}$ large ribosomal RNA, rRNA & 1900,5000 & Translation \\
\hline Messenger RNAs, mRNAs & Various & Templates for protein biosynthesis \\
\hline $\begin{array}{l}\text { Long intervening non-protein-coding } \\
\text { RNAs, lincRNAs }\end{array}$ & Various & $\begin{array}{l}\text { Various suggested functions, not many are certain; } \\
\text { regulation of gene expression; gene/ } \\
\text { chromosome silencing/imprinting by } \\
\text { interaction with chromatin }\end{array}$ \\
\hline Enhancer RNA, eRNA & $>1000$ & \\
\hline Multiexonic poly $(\mathrm{A})^{+}$RNA, meRNA & Various & \\
\hline $\begin{array}{l}\text { Long antisense RNAs, asRNA, or aRNA or } \\
\text { natural antisense RNA, NAS RNA }\end{array}$ & Various & Possibly regulation of gene expression \\
\hline Pseudogene transcripts & Various & Decoy or sink for sequestration of RNA or protein \\
\hline Circular RNA & & Decoy or sink for sequestration of RNA or protein \\
\hline
\end{tabular}

It is difficult to classify RNAs because they are so diverse. This table attempts to categorize according to size; other groupings take their subcellular locations or functions into account. In any event, the distinctions are blurry and apply only to one species or lineage. In yeast, for example, the U-type snRNAs are significantly larger than in vertebrates. More recently, an arbitrary line between large and small RNAs is being drawn at $200 \mathrm{nt}$, the latter including tiny RNAs, such as miRNAs. The three size classes here reflect the historical division between small and large RNA at 500 nt to accommodate SRP RNA, 7SK RNA, or mitochondrial RNA processing (MRP) RNA that are well $>200$ nt in length, but have been known since their discoveries as small RNAs. Large or long RNAs are defined as being in the size range of mRNAs, sometimes even displaying mRNA-like attributes (e.g., processing, polyadenylation), but devoid of a functional open reading frame. Initially, miRNAs were designated as tiny RNAs to distinguish them from conventional small RNAs (Ruvkun 2001). This tripartite categorization is kept in the table. There is a flurry of attempts to identify additional RNA classes. Their functions are mostly unknown and the RNAs might correspond to spurious or aborted transcription or other by-products of gene expression (see the text). These include promoter-associated short and long RNA (PASR, PALR), termini-associated RNA (TASR), promoter upstream RNA (PROMPT) transcription initiated RNA (tiRNA), transcription start site antisense RNA (TSSa), antisense termini-associated short RNA (aTASR), retrotransposon derived RNA, satellite region RNA, telomere repeat region antisense RNA (TERRA), etc. For further information and original references see Saxena and Carninci (2011a). PIWI, P-element-induced wimpy testis.

times over (Carninci 2009; Ritz et al. 2011; Haas et al. 2012; Ho et al. 2012; Shah et al. 2012; An et al. 2013; Eswaran et al. 2013; Hu et al. 2013; Schonberg et al. 2013; Yoshihara et al. 2013). With all this overabundance, there is a debate raging between those that claim almost any identified transcript and snippet of RNA to be functional (Mattick 2003; Lee et al. 2009; Carninci 2010; Kishore et al. 2010; Clark et al. 2011; Bernstein et al. 2012; Kapranov and St Laurent 2012; Khayrullina et al. 2012; Gebetsberger and Polacek 2013; Mattick and Dinger 2013) and more conservative voices (Brosius 2005c; Huttenhofer et al. 2005; Robinson 2010; van Bakel et al. 2010; Graur et al. 2013). The writer concurs with the argumentation for spurious and stochastic transcripts (Kowalczyk et al. 2012; Jensen et al. 2013; Mudge et al. 2013), especially as many transcription promoters are bidirec- tional (Seila et al. 2008; Neil et al. 2009; Xu et al. 2009; Wei et al. 2011; Uesaka et al. 2014). Even the yeast Saccharomyces cerevisiae featuring a compact genome abounds with transcriptional noise and erroneous initiation of transcription by RNA polymerase II (Struhl 2007). Furthermore, some transcription might be involved in gene regulation without the transcribed RNA being functional (Tisseur et al. 2011). Examples include regulation of transcription by upstream promoters, previously known as promoter occlusion or transcriptional interference (Adhya and Gottesman 1982; Cullen et al. 1984). In yeast, for example, it has been shown that the SER3 gene is repressed by the act of transcription from the upstream SRG1 gene (Martens et al. 2004). In contrast, the PHO5 gene is activated by intergenic transcription in the opposite orientation presumably influenc- 
ing chromatin remodeling (Uhler et al. 2007). In other words, the act of transcription exerts the function whereas the RNA is merely a byproduct, and this mechanism regulates gene expression in multicellular eukaryotes as well (Kornienko et al. 2013). Another relatively passive role for some RNAs could be the following: Many proteins can bind RNA and proteins can associate with each other. Perhaps an RNA molecule could have the sole function to broker the interaction of two or more proteins that otherwise would not be able to interact with each other. However, if the proteins bind directly or even via other RNA binding proteins to the RNA, close proximity might facilitate functional or structural interactions. In addition, such an RNP complex might even serve as a shuttle into subcellular domains or environments that one or the other component, for lack of the appropriate signals, would not be able to reach by itself (Brosius 2005b).

It has been argued that many of the newly discovered long RNAs represent 3'-UTRs extending beyond the annotated $3^{\prime}$-ends of the mRNAs by using alternative distal poly(A) addition signals. If there are large introns, $5^{\prime}$-UTRs with alternative upstream promoters also can be located far from the ORF. For that reason, some investigators took measures to stay clear of transcripts that are located in a certain proximity to annotated protein-coding genes (Managadze et al. 2013). Nevertheless, splicing does occur in 3'-UTRs as well (Bicknell et al. 2012; Camacho-Vanegas et al. 2012; Zhernakova et al. 2013) and, hence, the corresponding exons could map to corresponding protein-coding genes at a much greater distance to the ORFs. Furthermore, apart from spurious initiation of transcription anywhere in the genome, a certain level of readthrough into gene distal regions could account for a significant portion of these long RNA candidates (Finta and Zaphiropoulos 2000; Akiva et al. 2006; Parra et al. 2006; Richard and Manley 2009).

RNAs overlapping with annotated genes or transcribed in antisense orientation, albeit showing regulatory potential, are generally being avoided for now as their structures, regulation, and functions are more difficult to inves-
RNA and Eukaryotic Gene/Genome Architecture

tigate (Ulitsky and Bartel 2013). Hence, the focus has narrowed to investigating long intergenic noncoding RNAs (lincRNAs). ${ }^{8}$ Another point is being overlooked frequently. For the most part, the arbitrary cutoff for an open reading frame is at 100 amino acids in length. If humans were not pentadactyls, but hexa- or tetradactyls, the cutoff would probably have been chosen at 144 or 64 amino acids, respectively. There are numerous mRNAs that have even shorter ORFs, namely, those encoding peptides (Rudd et al. 1998; Sousa et al. 2001; Frith et al. 2006a; Kastenmayer et al. 2006; Savard et al. 2006; Galindo et al. 2007; Ghabrial 2007; Hanada et al. 2007; Hashimoto et al. 2008; Magny et al. 2013). Perhaps a significant fraction of mRNA-like long intervening non-protein-coding RNAs are mRNAs after all, encoding peptides and short proteins. The question on how many of the non-protein-coding RNAs are associated with polysomes for productive translation is currently under debate (Ingolia et al. 2011; Guttman et al. 2013; Ingolia et al. 2013; Ulitsky and Bartel 2013; van Heesch et al. 2014).

\section{NOVEL RNAs OUT OF THE BLUE}

De novo arisen long (intergenic or better intervening) non-protein-coding RNA genes out of neutrally evolving DNA including transposed elements also are receiving increased attention (Guttman et al. 2009; Marques and Ponting 2009; Esteller 2011; Hadjiargyrou and Delihas 2013; Kapusta et al. 2013; Managadze et al. 2013; Ulitsky and Bartel 2013). Their abundance as a class is not surprising, however, because parts of TEs, especially LINEs and lone LTRs, can harbor active transcription promoters. As a consequence, a large proportion of long intervening non-protein-coding RNAs show sequence similarities to TEs.

\footnotetext{
${ }^{8}$ This is a double blunder in the troubled RNA nomenclature. First, there hardly is a bona fide noncoding RNA (except, of course, for the nonfunctional noise) and most RNAs carry a code (Trifonov 1989; Barbieri 2003), and, second, if the locus encodes an RNA, it is a gene itself and not something intergenic. At least one laboratory has begun to address these macromolecules as long "intervening" non[protein]-coding RNAs (Ulitsky and Bartel 2013).
} 
J. Brosius

Most investigators agree that among the tens of thousands of long RNA candidates, there will be hundreds if not thousands of bona fide functional RNAs. One article estimates the number to be $\sim 10 \%$ of all suggested candidates (Ulitsky and Bartel 2013). In addition, quite a few of these spurious and currently nonfunctional RNAs might one day be exapted into novel functions and, as discussed above, as protein-coding exons or regulatory regions. The majority will be rendered inactive again and a few, if beneficial, will eventually persist under selective pressure (Brosius 2005c; Siepel 2009; Polev 2012). In an analogy to Alex Rich's predictions with respect to an RNA world and the persisting significance of RNA, Henry Harris envisaged the potential of spurious transcripts as raw material for evolution about half a century ago: "Only a small proportion of the RNA made in the nucleus of animal and higher plant cells serves as a template for the synthesis of protein. ... Most of the nuclear RNA, however, is made on parts of the DNA, which do not contain information for the synthesis of specific proteins. ... It plays no role in the synthesis of a cell protein, but serves as a background on which mutation and selection may operate to produce new templates for protein synthesis" (Harris 1965, 2013). This also applies to new genes encoding functional RNAs.

The process of new genes arising out of nongenic regions might not appear as extraordinary if one considers the presumably more trivial reverse process, namely, formation and gradual decay of pseudogenes. A single-point mutation or small deletion can turn an mRNA into a nonprotein-coding RNA. Further mutations can silence its transcription and, after enough time, the remnants of a gene cannot be recognized as such any longer.

\section{COMPETITIVE RNAs}

Interestingly, transcribed pseudogenes, including those that arose via retroposition, reportedly can be functional as RNAs or mRNAs encoding truncated proteins (Balakirev and Ayala 2003; Duret et al. 2006; Frith et al. 2006b; Pink et al. 2011; Wen et al. 2012; Sen and Ghosh
2013). For example, retropseudogene PTENP1 derived from tumor suppressor gene PTEN is transcribed. Like the canonical mRNA expressed from the parent gene, it harbors binding sites for several miRNAs in what used to be the 3'-UTR. These miRNA target sites are competing for the corresponding miRNAs, thus, ameliorating their inhibitory effect on the intact mRNA, resulting in higher levels of the tumor suppressor protein PTEN (Poliseno et al. 2010). Even two isoforms of an antisense RNA generated from the PTENP1 pseudogene have been reported to be involved in gene regulation (Johnsson et al. 2013). In addition, a plethora of naturally occurring circular RNAs have been discovered, which may regulate gene expression by sponging up complementary RNAs, such as miRNAs (Salzman et al. 2012; Hansen et al. 2013; Memczak et al. 2013; Tay et al. 2014). RNAs not only can be decoys or sinks for other RNAs but also for proteins. A long RNA processing product located between two snoRNAs has been reported to act as a sink for Fox 2 splicing factor and, as a consequence, alter the relative abundance of alternative splice products of a number of genes (Yin et al. 2012).

\section{THE (NUCLEIC) ACID TEST FOR FUNCTION}

As one of the early advocates of a vibrant RNA componentry in extant organisms (DeChiara and Brosius 1987; Brosius 1991, 1996; Petherick 2008), the writer never doubted that the number of functional non-protein-coding RNAs could easily match those for mRNAs in line with more conservative estimates being in the 3\% range (Clamp et al. 2007; Church et al. 2009; Cabili et al. 2011; Managadze et al. 2013). ${ }^{9}$ Considering genes encoding RNAs smaller than

\footnotetext{
${ }^{9}$ ORFs amount to $\sim 1.3 \%$ in the mouse and human genomes and an additional $\sim 0.8 \%$ serve as $5^{\prime}$ - and $3^{\prime}$-UTRs at their extremities (International Human Genome Sequencing Consortium 2004; Church et al. 2009; Managadze et al. 2013). Accordingly, all sequences that end up in mature mRNAs cover somewhat $>2 \%$ of their respective genomes. Strictly speaking, mRNAs are chimera between templates for translation and non-protein-coding RNAs and many long (intervening) non-protein-coding RNAs are quite similar, except for the lack of (long) ORFs.
} 
long RNAs as well and leaving generous space for potentially functional RNAs overlapping other genes in sense or antisense orientation, the figure might top 5\%. It does not matter whether the numbers will end up even at $10 \%$ of the total genome, they will not be in the range of 75\% (Djebali et al. 2012). There is a tremendous task ahead of us to determine which of the detected transcripts are bona fide RNAs, and what their individual functions and contributions to the cell are. Phylogenetic conservation helps, but its absence is not a perfect criterion for lack of function. Not many investigators would deny the functional significance of the UTRs of mRNAs. These regions, flanking ORFs, can encode other, for example, regulatory functions such as structures to modulate turnover or translation efficiencies, including sequence complementarities to regulatory miRNAs. Yet, for the most part, these sequences show much less phylogenetic conservation in comparison to ORFs. This agrees with findings about Xist, an 17-kb-long non-protein-coding RNA in humans that, at best, is conserved only in small patches between mammals (Duret et al. 2006). Inactivation of Xist RNA expression on the paternal $\mathrm{X}$ chromosome leads to early embryonic death in a mouse knockout model (Marahrens et al. 1997). Even the best test for functional significance, gene inactivation in knockout model systems, does not always provide immediate and simple answers. In yeast, very few knockouts of snoRNAs showed a clear phenotype as was the case for U14 (Li et al. 1990), but not, for example, snR189 (Thompson et al. 1988), or only over time or under certain conditions with respect to other snoRNAs (Badis et al. 2003; King et al. 2003; Esguerra et al. 2008). Bacterial genomes like those of Escherichia coli do not have much space to waste and everything without a selective advantage would not remain in the genome for long. In agreement, the knockout of the 4.5S RNA gene had been shown to be essential (Brown and Fournier 1984). Surprisingly, ablation of the gene encoding 6S RNA with a wide phylogenetic distribution and structural conservation in bacteria (Barrick et al. 2005) had no effect on immediate viability (Lee et al. 1985). Later, 6S
RNA was shown to regulate transcription and enhance long-term survival (Wassarman and Storz 2000; Trotochaud and Wassarman 2004).

In mammalian genomes, not every inactivation of a protein-coding gene results in a discernible phenotype. The same is to be expected from genes encoding RNA. Snora35 is located within the second intron (almost $100 \mathrm{~kb}$ in length) of the serotonin $2 c$ receptor gene (Htr2c) and is highly conserved between placental mammals. As a consequence, the brain-specific Snora35 (earlier termed MBI-36 snoRNA) is cotranscribed with and processed out of the primary Htr2c heterogeneous nuclear RNA (hnRNA), for example, in the choroid plexus (Cavaille et al. 2000). Snora35 gene-depleted mice do not appear to display a phenotype different from their wild-type siblings, thus far (BV Skryabin and J Brosius, unpubl.). In another example of an RNA knockout, it took several years of work to tease out a reduced exploratory behavior in mice when small cytoplasmic BC1 RNA, phylogenetically restricted to rodents and expressed in neurons where it is delivered to dendritic processes, was deleted (Tiedge et al. 1991; Martignetti and Brosius 1993; Lewejohann et al. 2004). In a further mouse snoRNA knockout, the entire cluster encoding Snord116 RNA isoforms (earlier termed MBII-85 snoRNA) was deleted from a locus associated with Prader-Willi syndrome, a neurodevelopmental disorder in humans. Two independent studies revealed that the mice showed failure to thrive and growth retardation, but not all symptoms described for humans (Skryabin et al. 2007; Ding et al. 2008). In many multicellular organisms, snoRNAs are cotranscribed with introns of protein-coding genes or nonprotein-coding genes. Snord116 is paternally imprinted and expressed in the brain. The host RNA is processed into a set of abundant long non-protein-coding RNAs by splicing out the introns (Runte et al. 2001). Attempts to compensate for the loss of Snord 116 with constructs coexpressing some copies of the respective snoRNA in introns of a different host transgene independently failed thus far (Ding et al. 2008; BV Skryabin and J Brosius, unpubl.). The following could explain the findings: (1) The num- 
ber of Snord116 RNA isoforms from the original transcription unit is not sufficient in the transgenic construct; (2) spatial, temporal expression and/or its levels are not appropriate; and (3) truncation of the long host hnRNAderived, processed non-protein-coding RNA is the underlying cause for the mouse phenotype and, by extension, human disease.

An interesting case involves the Hotair long RNA that had been shown ex vivo to regulate HoxD genes (Rinn et al. 2007); deletion of the HoxC cluster harboring the Hotair gene was devoid of a phenotype (Schorderet and Duboule 2011), whereas targeted disruption of the Hotair locus alone led to homeotic transformation of the spine and malformation of metacarpal and carpal bones (Li et al. 2013).

A great stride forward has been made through a comprehensive gene knockout project involving 18 large RNA candidates (Sauvageau et al. 2013). The corresponding genes were selected not to overlap with any other gene or gene module, and their coding regions were replaced with the lac $\mathrm{Z}$ and $n e o^{\mathrm{R}}$ marker genes. At the current level of investigation, five of the 18 mouse lines revealed a phenotype. In three lines peri- and postnatal lethality was reported, two of which had some survivors, but they had growth defects. For the two remaining lines with a phenotype, growth defects were also reported. The most lethal knockout involved Fendrr, a gene with six exons encoding a nuclear RNA of about $2.4 \mathrm{~kb}$ in length. An independent knockout only involving the first exon by inserting a transcriptional stop cassette was lethal as well, albeit showing different organ defects (Grote et al. 2013). The $<30 \%$, but $>10 \%$ "success" rate of 18 knockouts could mean a number of things, for example, that the RNA gene candidates were carefully selected in favor of potential functionality and phenotypic consequences (Sauvageau et al. 2013). Still, two-thirds of the gene ablations did not show a noticeable impact under the laboratory conditions tested, but, nevertheless, could be beneficial for the longterm survival of mice in natural, ever-changing environments or that some of the RNAs have no function per se. Also, it remains valid that, in exceptional cases, such transitory "protogenes" could become exaptations encoding novel functional RNAs, even proteins, or predominantly disappear again into the noise of the neutrally evolving genomic mass. In any event, major points in an article written to balance some of the extreme views are confirmed: "[ $\mathrm{t}$ ] here is no doubt that a number of these non-protein-coding RNAs have important regulatory functions in the cell" and ". . . aberrant transcripts or processing products embody evolutionary potential and provide novel RNAs that natural selection can act on" (Brosius 2005c).

\section{CONCLUDING REMARKS}

All scenarios for the beginning of life are far from perfect. The most plausible hypothesis is based on RNA as a primordial (auto)catalytic macromolecule, leading over a variety of transitions (Cairns-Smith 1982; Szathmáry and Smith 1995), of which one of the first was acquisition of a simple lipid enclosure (Szostak et al. 2001; Mansy et al. 2008) to extant forms of life. In the RNA world, pheno- and genotype were united in the same macromolecule. This union began to separate during the major transition to the RNP world with a "division of labor" between RNA and protein. Even before, linkage of RNA molecules, confinement (of sets of RNAs), and discrimination, on one hand, versus escape (reminiscent of viruses and horizontal gene transfer) and more expansive exchange by reshuffling of the RNA componentry (sex), are apparent. This resembles a tug of war, constantly in need of balancing the forces and not allowing for a victory of either side. Up to this day, at the cellular, organismal, and societal level, the predicament of discrimination and exchange as well as the quandary of selfishness and cooperation remains an essence of evolution and life. ${ }^{10}$

Perhaps the modular arrangement of genes and chromosomal DNA has its origins in the

\footnotetext{
10"Without Contraries is no progression. Attraction and Repulsion [...] are necessary to [...] existence." The original William Blake quote, not shortened by the writer is given as: "Without Contraries is no progression. Attraction and Repulsion, Reason and Energy, Love and Hate, are necessary to Human existence" (Blake 1975).
} 
RNA and Eukaryotic Gene/Genome Architecture

RNA or RNP worlds as well, reflecting the hypothetical structure of several linked RNA molecules. This also would mean that RNA processing and trimming had very early origins. Components of the extant telomerase as well as group II introns, ancestral to the spliceosome and non-LTR retroposons, might date back as far as the RNP or RNA worlds. The continued assault of extant eukaryotic genomes with retroposons (somewhat countered and alleviated by deletions via recombination) clearly had its origin in the transition period when RNA was replaced by DNA for the task of storing and replicating genetic material. This process still can shape genomes quite drastically in relatively short evolutionary time frames. Importantly, out of this sea of change with islands of rather conserved and fixed gene modules, new modules can be generated fortuitously and "tested" for added or modified function by the forces of selection. Most disappear again with a few eventually exapted as novel gene modules and, occasionally, even as novel genes encoding protein or functional RNA.

After a long lag phase on the sidelines, functional RNA currently is in the spotlight of biology, even medicine, as RNomics shows promise to detect additional disease genes, greatly develop the diagnostic toolbox, and revolutionize therapeutic possibilities (Esteller 2011; Cech 2012; Erdmann and Barciszewski 2012; Gold et al. 2012). However, the development from only two decades ago when the mere mention of RNA generally exposed grant proposals to monkey hammering resulting in poorer scores and the current situation in which a feeding frenzy of RNA discovery fueled by ultradeep RNA-sequencing technologies endorses almost any detected transcript or degradation product as functional RNA borders on the grotesque. Clearly, the pendulum has swung to the other extreme. ${ }^{11}$ In any event, the renewed interest in RNA and advances in understanding its evolution and biology will continue to fascinate us. RNA, this ancient macromolecule, will grant us

\footnotetext{
${ }^{11}$ See zmbe.uni-muenster.de/institutes/iep/iepcartoon.htm for a cartoon.
}

exciting new insights into the works of life past, present, and possibly future.

\section{REFERENCES}

Aalto AP, Pasquinelli AE. 2012. Small non-coding RNAs mount a silent revolution in gene expression. Curr Opin Cell Biol 24: 333-340.

Adamala K, Szostak JW. 2013. Nonenzymatic templatedirected RNA synthesis inside model protocells. Science 342: $1098-1100$.

Adhya S, Gottesman M. 1982. Promoter occlusion: Transcription through a promoter may inhibit its activity. Cell 29: 939-944.

Ahituv N, Zhu Y, Visel A, Holt A, Afzal V, Pennacchio LA, Rubin EM. 2007. Deletion of ultraconserved elements yields viable mice. PLoS Biol 5: e234.

Akiva P, Toporik A, Edelheit S, Peretz Y, Diber A, Shemesh R, Novik A, Sorek R. 2006. Transcription-mediated gene fusion in the human genome. Genome Res 16: 30-36.

Allen TA, Von Kaenel S, Goodrich JA, Kugel JF. 2004. The SINE-encoded mouse B2 RNA represses mRNA transcription in response to heat shock. Nat Struct Mol Biol 11: $816-821$.

Ambros V. 2001. microRNAs: Tiny regulators with great potential. Cell 107: 823-826.

An J, Lai J, Lehman ML, Nelson CC. 2013. miRDeep*: An integrated application tool for miRNA identification from RNA sequencing data. Nucleic Acids Res 41: 727737.

Atkins JF, Gesteland RF, Cech TR. 2011. RNA Worlds: From life's origins to diversity in gene regulation. Cold Spring Harbor Laboratory Press, Cold Spring Harbor, NY.

Attwater J, Wochner A, Holliger P. 2013. In-ice evolution of RNA polymerase ribozyme activity. Nat Chem 5: 10111018.

Babushok DV, Ostertag EM, Kazazian HH Jr. 2007. Current topics in genome evolution: Molecular mechanisms of new gene formation. Cell Mol Life Sci 64: 542-554.

Badis G, Fromont-Racine M, Jacquier A. 2003. A snoRNA that guides the two most conserved pseudouridine modifications within rRNA confers a growth advantage in yeast. RNA 9: 771-779.

Baertsch R, Diekhans M, Kent WJ, Haussler D, Brosius J. 2008. Retrocopy contributions to the evolution of the human genome. BMC Genomics 9: 466.

Bailey JA, Eichler EE. 2006. Primate segmental duplications: Crucibles of evolution, diversity and disease. Nat Rev Genet 7: 552-564.

Baillie JK, Barnett MW, Upton KR, Gerhardt DJ, Richmond TA, De Sapio F, Brennan PM, Rizzu P, Smith S, Fell M, et al. 2011. Somatic retrotransposition alters the genetic landscape of the human brain. Nature 479: 534-537.

Balakirev ES, Ayala FJ. 2003. Pseudogenes: Are they "junk" or functional DNA? Annu Rev Genet 37: 123-151.

Barbieri M. 2003. The organic codes: An introduction to semantic biology. Cambridge University Press, Cambridge.

Barrick JE, Sudarsan N, Weinberg Z, Ruzzo WL, Breaker RR 2005. 6S RNA is a widespread regulator of eubacterial 
J. Brosius

RNA polymerase that resembles an open promoter. RNA 11: 774-784.

Bejerano G, Lowe CB, Ahituv N, King B, Siepel A, Salama SR, Rubin EM, Kent WJ, Haussler D. 2006. A distal enhancer and an ultraconserved exon are derived from a novel retroposon. Nature 441: 87-90.

Benner SA. 1988. Extracellular "communicator RNA." FEBS Lett 233: 225-228.

Bernstein BE, Birney E, Dunham I, Green ED, Gunter C, Snyder M. 2012. An integrated encyclopedia of DNA elements in the human genome. Nature 489: 57-74.

Bicknell AA, Cenik C, Chua HN, Roth FP, Moore MJ. 2012. Introns in UTRs: Why we should stop ignoring them. BioEssays 34: 1025-1034.

Birney E, Stamatoyannopoulos JA, Dutta A, Guigo R, Gingeras TR, Margulies EH, Weng Z, Snyder M, Dermitzakis ET, Thurman RE, et al. 2007. Identification and analysis of functional elements in $1 \%$ of the human genome by the ENCODE pilot project. Nature 447: 799-816.

Blackburn EH, Collins K. 2011. Telomerase: An RNP enzyme synthesizes DNA. Cold Spring Harb Perspect Biol 3: a003558.

Blackburn EH, Greider CW, Szostak JW. 2006. Telomeres and telomerase: The path from maize, Tetrahymena and yeast to human cancer and aging. Nat Med 12: 11331138.

Blake W. 1975. The marriage of heaven and hell. Oxford University Press, Oxford (first published in 1790).

Bourque G, Leong B, Vega VB, Chen X, Lee YL, Srinivasan KG, Chew JL, Ruan Y, Wei CL, Ng HH, et al. 2008. Evolution of the mammalian transcription factor binding repertoire via transposable elements. Genome Res 18: $1752-1762$.

Bridges CB. 1936. The bar "gene" a duplication. Science 83: 210-211.

Brosius J. 1991. Retroposons-Seeds of evolution. Science 251: 753.

Brosius J. 1996. More haemophilus and Mycoplasma genes. Science 271: 1302-1303.

Brosius J. 1999a. Genomes were forged by massive bombardments with retroelements and retrosequences. Genetica 107: 209-238.

Brosius J. 1999b. RNAs from all categories generate retrosequences that may be exapted as novel genes or regulatory elements. Gene 238: 115-134.

Brosius J. 2001. tRNAs in the spotlight during protein biosynthesis. Trends Biochem Sci 26: 653-656.

Brosius J. 2003a. The contribution of RNAs and retroposition to evolutionary novelties. Genetica 118: 99-116.

Brosius J. 2003b. From Eden to a hell of uniformity? Directed evolution in humans. BioEssays 25: 815-821.

Brosius J. 2003c. Gene duplication and other evolutionary strategies: From the RNA world to the future. J Struct Funct Genomics 3: 1-17.

Brosius J. 2005a. Disparity, causation, adaptation, exaptation, and contingency at the genome level. Paleobiology 31: $1-16$.

Brosius J. 2005b. Echoes from the past-Are we still in an RNP world? Cytogenet Genome Res 110: 8-24.
Brosius J. 2005c. Waste not, want not-Transcript excess in multicellular eukaryotes. Trends Genet 21: 287-288.

Brosius J. 2009. The fragmented gene. Ann NY Acad Sci 1178: $186-193$.

Brosius J, Gould SJ. 1992. On "genomenclature": A comprehensive (and respectful) taxonomy for pseudogenes and other "junk DNA." Proc Natl Acad Sci 89: 10706-10710.

Brown S, Fournier MJ. 1984. The 4.5 S RNA gene of Escherichia coli is essential for cell growth. J Mol Biol 178: $533-550$.

Bundo M, Toyoshima M, Okada Y, Akamatsu W, Ueda J, Nemoto-Miyauchi T, Sunaga F, Toritsuka M, Ikawa D, Kakita A, et al. 2014. Increased 11 retrotransposition in the neuronal genome in schizophrenia. Neuron 81: 306-313.

Cabili MN, Trapnell C, Goff L, Koziol M, Tazon-Vega B, Regev A, Rinn JL. 2011. Integrative annotation of human large intergenic noncoding RNAs reveals global properties and specific subclasses. Genes Dev 25: 1915-1927.

Cairns-Smith AG. 1982. Genetic takeover and the mineral origins of life. Cambridge University Press, Cambridge.

Camacho-Vanegas O, Camacho SC, Till J, Miranda-Lorenzo I, Terzo E, Ramirez MC, Schramm V, Cordovano G, Watts G, Mehta S, et al. 2012. Primate genome gain and loss: A bone dysplasia, muscular dystrophy, and bone cancer syndrome resulting from mutated retroviral-derived MTAP transcripts. Am J Hum Genet 90: 614-627.

Carninci P. 2009. Is sequencing enlightenment ending the dark age of the transcriptome? Nat Methods 6: 711-713.

Carninci P. 2010. RNA dust: Where are the genes? DNA Res 17: $51-59$.

Carninci P, Kasukawa T, Katayama S, Gough J, Frith MC, Maeda N, Oyama R, Ravasi T, Lenhard B, Wells C, et al. 2005. The transcriptional landscape of the mammalian genome. Science 309: 1559-1563.

Carrieri C, Cimatti L, Biagioli M, Beugnet A, Zucchelli S, Fedele S, Pesce E, Ferrer I, Collavin L, Santoro C, et al. 2012. Long non-coding antisense RNA controls Uchll translation through an embedded SINEB2 repeat. Nature 491: 454-457.

Carvunis AR, Rolland T, Wapinski I, Calderwood MA, Yildirim MA, Simonis N, Charloteaux B, Hidalgo CA, Barbette J, Santhanam B, et al. 2012. Proto-genes and de novo gene birth. Nature 487: 370-374.

Cavaille J, Buiting K, Kiefmann M, Lalande M, Brannan CI, Horsthemke B, Bachellerie JP, Brosius J, Huttenhofer A. 2000. Identification of brain-specific and imprinted small nucleolar RNA genes exhibiting an unusual genomic organization. Proc Natl Acad Sci 97: 14311-14316.

Cavalier-Smith T. 1991. Intron phylogeny: A new hypothesis. Trends Genet 7: 145-148.

Cech TR. 2012. The RNA worlds in context. Cold Spring Harb Perspect Biol 4: a006742.

Chen S, Krinsky BH, Long M. 2013. New genes as drivers of phenotypic evolution. Nat Rev Genet 14: 645-660.

Cheng J, Kapranov P, Drenkow J, Dike S, Brubaker S, Patel S, Long J, Stern D, Tammana H, Helt G, et al. 2005. Transcriptional maps of 10 human chromosomes at 5-nucleotide resolution. Science 308: 1149-1154.

Church DM, Goodstadt L, Hillier LW, Zody MC, Goldstein S, She X, Bult CJ, Agarwala R, Cherry JL, DiCuccio M, 
et al. 2009. Lineage-specific biology revealed by a finished genome assembly of the mouse. PLoS Biol 7: e1000112.

Clamp M, Fry B, Kamal M, Xie X, Cuff J, Lin MF, Kellis M, Lindblad-Toh K, Lander ES. 2007. Distinguishing protein-coding and noncoding genes in the human genome. Proc Natl Acad Sci 104: 19428-19433.

Clark MB, Amaral PP, Schlesinger FJ, Dinger ME, Taft RJ, Rinn JL, Ponting CP, Stadler PF, Morris KV, Morillon A, et al. 2011. The reality of pervasive transcription. PLoS Biol 9: e1000625; discussion e1001102.

Cloutier SC, Wang S, Ma WK, Petell CJ, Tran EJ. 2013. Long noncoding RNAs promote transcriptional poising of inducible genes. PLoS Biol 11: e1001715.

Costa FF. 2010. Non-coding RNAs: Meet thy masters. BioEssays 32: 599-608.

Coufal NG, Garcia-Perez JL, Peng GE, Yeo GW, Mu Y, Lovci MT, Morell M, O’Shea KS, Moran JV, Gage FH. 2009. L1 retrotransposition in human neural progenitor cells. Nature 460: 1127-1131.

Couzin J. 2002. Breakthrough of the year. Small RNAs make big splash. Science 298: 2296-2297.

Crick FH. 1958. On protein synthesis. Symp Soc Exp Biol 12: $138-163$.

Crick FH. 1968. The origin of the genetic code. J Mol Biol 38: $367-379$.

Crick F. 1970. Central dogma of molecular biology. Nature 227: $561-563$.

Cullen BR, Lomedico PT, Ju G. 1984. Transcriptional interference in avian retroviruses-Implications for the promoter insertion model of leukaemogenesis. Nature 307: 241-245.

Darnell JE, Doolittle WF. 1986. Speculations on the early course of evolution. Proc Natl Acad Sci 83: 1271-1275.

Deamer D. 2005. A giant step towards artificial life? Trends Biotechnol 23: 336-338.

DeChiara TM, Brosius J. 1987. Neural BC1 RNA: cDNA clones reveal nonrepetitive sequence content. Proc Natl Acad Sci 84: $2624-2628$

de Koning AP, Gu W, Castoe TA, Batzer MA, Pollock DD 2011. Repetitive elements may comprise over two-thirds of the human genome. PLoS Genet 7: e1002384.

Derrien T, Johnson R, Bussotti G, Tanzer A, Djebali S, Tilgner H, Guernec G, Martin D, Merkel A, Knowles DG, et al. 2012. The GENCODE v7 catalog of human long noncoding RNAs: Analysis of their gene structure, evolution, and expression. Genome Res 22: 1775-1789.

de Souza FS, Franchini LF, Rubinstein M.. 2013. Exaptation of transposable elements into novel cis-regulatory elements: Is the evidence always strong? Mol Biol Evol 30: 1239-1251.

Dieci G, Conti A, Pagano A, Carnevali D. 2013. Identification of RNA polymerase III-transcribed genes in eukaryotic genomes. Biochim Biophys Acta 1829: 296-305.

Ding F, Li HH, Zhang S, Solomon NM, Camper SA, Cohen P, Francke U. 2008. SnoRNA Snord116 (Pwcr1/MBII-85) deletion causes growth deficiency and hyperphagia in mice. PloS ONE 3: e1709.

Di Ruscio A, Ebralidze AK, Benoukraf T, Amabile G, Goff LA, Terragni J, Figueroa ME, De Figueiredo Pontes LL, Alberich-Jorda M, Zhang P, et al. 2013. DNMT1-inter-
RNA and Eukaryotic Gene/Genome Architecture

acting RNAs block gene-specific DNA methylation. Nature 503: 371-376.

Djebali S, Davis CA, Merkel A, Dobin A, Lassmann T, Mortazavi A, Tanzer A, Lagarde J, Lin W, Schlesinger F, et al. 2012. Landscape of transcription in human cells. Nature 489: $101-108$.

Doolittle WF. 2013. Is junk DNA bunk? A critique of ENCODE. Proc Natl Acad Sci 110: 5294-5300.

Doudna JA, Szostak JW. 1989. RNA-catalysed synthesis of complementary-strand RNA. Nature 339: 519-522.

Du ZQ, Yang CX, Rothschild MF, Ross JW. 2013. Novel microRNA families expanded in the human genome. BMC Genomics 14: 98.

Dunoyer P, Himber C, Ruiz-Ferrer V, Alioua A, Voinnet O. 2007. Intra- and intercellular RNA interference in Arabidopsis thaliana requires components of the microRNA and heterochromatic silencing pathways. Nat Genet 39: 848-856.

Duret L, Chureau C, Samain S, Weissenbach J, Avner P. 2006. The Xist RNA gene evolved in eutherians by pseudogenization of a protein-coding gene. Science 312: $1653-$ 1655.

Eigen M, Schuster P. 1977. The hypercycle. A principle of natural self-organization: Part A. Emergence of the hypercycle. Naturwissenschaften 64: 541-565.

Eigen M, Schuster P. 1978. The hypercycle. A principle of natural self-organization: Part C. The realistic hypercycle. Naturwissenschaften 65: 341-369.

Ellington AD, Szostak JW. 1990. In vitro selection of RNA molecules that bind specific ligands. Nature 346: $818-822$.

Ellison CE, Bachtrog D. 2013. Dosage compensation via transposable element mediated rewiring of a regulatory network. Science 342: 846-850.

Erdmann VA, Barciszewski J. 2012. From nucleic acids sequences to molecular medicine. Springer, Berlin.

Erdmann VA, Wolters J. 1987. The Berlin RNA Databank. Protein Seq Data Anal 1: 127.

Esguerra J, Warringer J, Blomberg A. 2008. Functional importance of individual rRNA $2^{\prime}$-O-ribose methylations revealed by high-resolution phenotyping. RNA 14: 649-656.

Espinoza CA, Allen TA, Hieb AR, Kugel JF, Goodrich JA. 2004. B2 RNA binds directly to RNA polymerase II to repress transcript synthesis. Nat Struct Mol Biol 11: 822-829.

Espinoza CA, Goodrich JA, Kugel JF. 2007. Characterization of the structure, function, and mechanism of B2 RNA, an ncRNA repressor of RNA polymerase II transcription. RNA 13: 583-596.

Esteller M. 2011. Non-coding RNAs in human disease. Nat Rev Genet 12: 861-874.

Eswaran J, Horvath A, Godbole S, Reddy SD, Mudvari P, Ohshiro K, Cyanam D, Nair S, Fuqua SA, Polyak K, et al. 2013. RNA sequencing of cancer reveals novel splicing alterations. Sci Rep 3: 1689.

Fatica A, Bozzoni I. 2014. Long non-coding RNAs: New players in cell differentiation and development. Nat Rev Genet 15: 7-21. 
J. Brosius

Faulkner GJ, Kimura Y, Daub CO, Wani S, Plessy C, Irvine KM, Schroder K, Cloonan N, Steptoe AL, Lassmann T, et al. 2009. The regulated retrotransposon transcriptome of mammalian cells. Nat Genet 41: 563-571.

Ferat JL, Michel F. 1993. Group II self-splicing introns in bacteria. Nature 364: 358-361.

Feschotte C. 2008. Transposable elements and the evolution of regulatory networks. Nat Rev Genet 9: 397-405.

Feuchter A, Mager D. 1990. Functional heterogeneity of a large family of human LTR-like promoters and enhancers. Nucleic Acids Res 18: 1261-1270.

Fica SM, Tuttle N, Novak T, Li NS, Lu J, Koodathingal P, Dai Q, Staley JP, Piccirilli JA. 2013. RNA catalyses nuclear premRNA splicing. Nature 503: 229-234.

Filipowicz W. 2000. Imprinted expression of small nucleolar RNAs in brain: Time for RNomics. Proc Nat Acad Sci 97: 14035-14037.

Fink GR. 1987. Pseudogenes in yeast? Cell 49: 5-6.

Finta C, Zaphiropoulos PG. 2000. The human cytochrome P450 3A locus. Gene evolution by capture of downstream exons. Gene 260: 13-23.

Fire A, Xu S, Montgomery MK, Kostas SA, Driver SE, Mello CC. 1998. Potent and specific genetic interference by double-stranded RNA in Caenorhabditis elegans. Nature 391: 806-811.

Frith MC, Forrest AR, Nourbakhsh E, Pang KC, Kai C, Kawai J, Carninci P, Hayashizaki Y, Bailey TL, Grimmond SM. 2006a. The abundance of short proteins in the mammalian proteome. PLoS Genet 2: e52.

Frith MC, Wilming LG, Forrest A, Kawaji H, Tan SL, Wahlestedt C, Bajic VB, Kai C, Kawai J, Carninci P, et al. 2006b. Pseudo-messenger RNA: Phantoms of the transcriptome. PLoS Genet 2: e23.

Galindo MI, Pueyo JI, Fouix S, Bishop SA, Couso JP. 2007. Peptides encoded by short ORFs control development and define a new eukaryotic gene family. PLoS Biol 5: e106.

Ganten D, Nesse R. 2012. The evolution of evolutionary molecular medicine: Genomics are transforming evolutionary biology into a science with new importance for modern medicine. J Mol Med (Berl) 90: 467-470.

Gebetsberger J, Polacek N. 2013. Slicing tRNAs to boost functional ncRNA diversity. RNA Biol 10: 1798-1806.

Geisler S, Coller J. 2013. RNA in unexpected places: Long non-coding RNA functions in diverse cellular contexts. Nat Rev Mol Cell Biol 14: 699-712.

Ghabrial A. 2007. Coding RNAs: Separating the grain from the chaff. Nat Cell Biol 9: 617-619.

Gilbert W. 1986. Origin of life-The RNA world. Nature 319: 618.

Gold L, Janjic N, Jarvis T, Schneider D, Walker JJ, Wilcox SK, Zichi D. 2012. Aptamers and the RNA world, past and present. Cold Spring Harb Perspect Biol 4: a003582.

Goldman A, Capoano CA, Gonzalez-Lopez E, Geisinger A. 2014. Identifier (ID) elements are not preferentially located to brain-specific genes: High ID element representation in other tissue-specific- and housekeeping genes of the rat. Gene 533: 72-77.
Gomes AQ, Nolasco S, Soares H. 2013. Non-coding RNAs: Multi-tasking molecules in the cell. Int J Mol Sci 14: 16010-16039.

Gong C, Maquat LE. 2011. lncRNAs transactivate STAU1mediated mRNA decay by duplexing with $3^{\prime}$ UTRs via Alu elements. Nature 470: 284-288.

Gould SJ. 2002. The structure of evolutionary theory. Belknap, Harvard University Press, Cambridge, MA.

Graur D, Zheng Y, Price N, Azevedo RB, Zufall RA, Elhaik E. 2013. On the immortality of television sets: "Function" in the human genome according to the evolution-free gospel of ENCODE. Genome Biol Evol 5: 578-590.

Greider CW, Blackburn EH. 1989. A telomeric sequence in the RNA of Tetrahymena telomerase required for telomere repeat synthesis. Nature 337: 331-337.

Grote P, Wittler L, Hendrix D, Koch F, Wahrisch S, Beisaw A, Macura K, Blass G, Kellis M, Werber M, et al. 2013. The tissue-specific lncRNA Fendrr is an essential regulator of heart and body wall development in the mouse. Dev Cell 24: $206-214$.

Guerrier-Takada C, Gardiner K, Marsh T, Pace N, Altman S. 1983. The RNA moiety of ribonuclease $\mathrm{P}$ is the catalytic subunit of the enzyme. Cell 35: 849-857.

Guthrie C. 1991. Messenger RNA splicing in yeast: Clues to why the spliceosome is a ribonucleoprotein. Science 253: 157-163.

Guttman M, Amit I, Garber M, French C, Lin MF, Feldser D, Huarte M, Zuk O, Carey BW, Cassady JP, et al. 2009. Chromatin signature reveals over a thousand highly conserved large non-coding RNAs in mammals. Nature 458: 223-227.

Guttman M, Russell P, Ingolia NT, Weissman JS, Lander ES. 2013. Ribosome profiling provides evidence that large noncoding RNAs do not encode proteins. Cell 154: $240-251$.

Haas BJ, Chin M, Nusbaum C, Birren BW, Livny J. 2012. How deep is deep enough for RNA-Seq profiling of bacterial transcriptomes? BMC Genomics 13: 734.

Hadjiargyrou M, Delihas N. 2013. The intertwining of transposable elements and non-coding RNAs. Int J Mol Sci 14: 13307-13328.

Haldane JBS. 1933. The part played by recurrent mutation in evolution. Am Nat 67: 5-9.

Hanada K, Zhang X, Borevitz JO, Li WH, Shiu SH. 2007. A large number of novel coding small open reading frames in the intergenic regions of the Arabidopsis thaliana genome are transcribed and/or under purifying selection. Genome Res 17: 632-640.

Hanczyc MM, Dorit RL. 1998. Experimental evolution of complexity: In vitro emergence of intermolecular ribozyme interactions. RNA 4: 268-275.

Hansen TB, Kjems J, Damgaard CK. 2013. Circular RNA and miR-7 in cancer. Cancer Res 73: 5609-5612.

Harris H. 1965. The short-lived RNA in the cell nucleus and its possible role in evolution. In Evolving genes and proteins (ed. Bryson V, Vogel HJ), pp. 469-500. Academic, New York.

Harris H. 2013. History: Non-coding RNA foreseen 48 years ago. Nature 497: 188. 
Hashimoto Y, Kondo T, Kageyama Y. 2008. Lilliputians get into the limelight: Novel class of small peptide genes in morphogenesis. Dev Growth Differ 50: S269-276.

Hayden EJ, Ferrada E, Wagner A. 2011. Cryptic genetic variation promotes rapid evolutionary adaptation in an RNA enzyme. Nature 474: 92-95.

Heinen TJ, Staubach F, Haming D, Tautz D. 2009. Emergence of a new gene from an intergenic region. Curr Biol 19: $1527-1531$.

Hiller M, Schaar BT, Bejerano G. 2012. Hundreds of conserved non-coding genomic regions are independently lost in mammals. Nucleic Acids Res 40: 11463-11476.

Ho DW, Yang ZF, Yi K, Lam CT, Ng MN, Yu WC, Lau J, Wan T, Wang X, Yan Z, et al. 2012. Gene expression profiling of liver cancer stem cells by RNA-sequencing. PloS ONE 7: e37159.

Hoffman Y, Dahary D, Bublik DR, Oren M, Pilpel Y. 2013. The majority of endogenous microRNA targets within Alu elements avoid the microRNA machinery. Bioinformatics 29: 894-902.

Holdt LM, Hoffmann S, Sass K, Langenberger D, Scholz M, Krohn K, Finstermeier K, Stahringer A, Wilfert W, Beutner $\mathrm{F}$, et al. 2013. Alu elements in ANRIL non-coding RNA at chromosome 9p21 modulate atherogenic cell functions through trans-regulation of gene networks. PLoS Genet 9: e1003588.

Hu W, Alvarez-Dominguez JR, Lodish HF. 2012. Regulation of mammalian cell differentiation by long non-coding RNAs. EMBO Rep 13: 971-983.

Hu Y, Huang Y, Du Y, Orellana CF, Singh D, Johnson AR, Monroy A, Kuan PF, Hammond SM, Makowski L, et al. 2013. DiffSplice: The genome-wide detection of differential splicing events with RNA-seq. Nucleic Acids Res 41: e39.

Huttenhofer A, Kiefmann M, Meier-Ewert S, O'Brien J, Lehrach H, Bachellerie JP, Brosius J. 2001. RNomics: An experimental approach that identifies 201 candidates for novel, small, non-messenger RNAs in mouse. $E M B O J \mathbf{2 0 :}$ 2943-2953.

Huttenhofer A, Schattner P, Polacek N. 2005. Non-coding RNAs: Hope or hype? Trends Genet 21: 289-297.

Iacoangeli A, Tiedge H. 2013. Translational control at the synapse: Role of RNA regulators. Trends Biochem Sci 38: $47-55$.

Ingolia NT, Lareau LF, Weissman JS. 2011. Ribosome profiling of mouse embryonic stem cells reveals the complexity and dynamics of mammalian proteomes. Cell 147: 789-802.

Ingolia NT, Brar GA, Rouskin S, McGeachy AM, Weissman JS. 2013. Genome-wide annotation and quantitation of translation by ribosome profiling. Current protocols in molecular biology (ed. Ausubel FM, et al.), Chap. 4, Unit 418.

International Human Genome Sequencing Consortium. 2004. Finishing the euchromatic sequence of the human genome. Nature 431: 931-945.

Jacquier A. 2009. The complex eukaryotic transcriptome Unexpected pervasive transcription and novel small RNAs. Nat Rev Genet 10: 833-844.

Jady BE, Ketele A, Kiss T. 2012. Human intron-encoded Alu RNAs are processed and packaged into Wdr79-associated nucleoplasmic box H/ACA RNPs. Genes Dev 26: $1897-$ 1910.

Jensen TH, Jacquier A, Libri D. 2013. Dealing with pervasive transcription. Mol Cell 52: 473-484.

Johnsson P, Ackley A, Vidarsdottir L, Lui WO, Corcoran M, Grander D, Morris KV. 2013. A pseudogene long-noncoding-RNA network regulates PTEN transcription and translation in human cells. Nat Struct Mol Biol 20: 440446.

Johnston WK, Unrau PJ, Lawrence MS, Glasner ME, Bartel DP. 2001. RNA-catalyzed RNA polymerization: Accurate and general RNA-templated primer extension. Science 292: $1319-1325$

Jordan IK, Rogozin IB, Glazko GV, Koonin EV. 2003. Origin of a substantial fraction of human regulatory sequences from transposable elements. Trends Genet 19: 68-72.

Joyce GF, Schwartz AW, Miller SL, Orgel LE. 1987. The case for an ancestral genetic system involving simple analogues of the nucleotides. Proc Natl Acad Sci 84: 43984402.

Kaessmann H. 2010. Origins, evolution, and phenotypic impact of new genes. Genome Res 20: 1313-1326.

Kapitonov VV, Jurka J. 2005. RAG1 core and V(D)J recombination signal sequences were derived from Transib transposons. PLoS Biol 3: e181.

Kapranov P, St Laurent G. 2012. Dark matter RNA: Existence, function, and controversy. Front Genet 3: 60.

Kapranov P, Ozsolak F, Milos PM. 2012. Profiling of short RNAs using Helicos single-molecule sequencing. Methods Mol Biol 822: 219-232.

Kapusta A, Kronenberg Z, Lynch VJ, Zhuo X, Ramsay L, Bourque G, Yandell M, Feschotte C. 2013. Transposable elements are major contributors to the origin, diversification, and regulation of vertebrate long noncoding RNAs. PLoS Genet 9: e1003470.

Kastenmayer JP, Ni L, Chu A, Kitchen LE, Au WC, Yang H, Carter CD, Wheeler D, Davis RW, Boeke JD, et al. 2006. Functional genomics of genes with small open reading frames (sORFs) in S. cerevisiae. Genome Res 16: 365-373.

Khayrullina GA, Raabe CA, Hoe CH, Becker K, Reinhardt R, Tang TH, Rozhdestvensky TS, Kopylov AM. 2012. Transcription analysis and small non-protein coding RNAs associated with bacterial ribosomal protein operons. Curr Med Chem 19: 5187-5198.

Kim J, Martignetti JA, Shen MR, Brosius J, Deininger P. 1994. Rodent BC1 RNA gene as a master gene for ID element amplification. Proc Natl Acad Sci 91: 3607-3611.

King TH, Liu B, McCully RR, Fournier MJ. 2003. Ribosome structure and activity are altered in cells lacking snoRNPs that form pseudouridines in the peptidyl transferase center. Mol Cell 11: 425-435.

Kishore S, Khanna A, Zhang Z, Hui J, Balwierz PJ, Stefan M, Beach C, Nicholls RD, Zavolan M, Stamm S. 2010. The snoRNA MBII-52 (SNORD 115) is processed into smaller RNAs and regulates alternative splicing. Hum $\mathrm{Mol} \mathrm{Ge}$ net 19: $1153-1164$.

Koonin EV. 2010. Taming of the shrewd: Novel eukaryotic genes from RNA viruses. BMC Biol 8: 2.

Kornienko AE, Guenzl PM, Barlow DP, Pauler FM. 2013. Gene regulation by the act of long non-coding RNA transcription. BMC Biol 11: 59. 
J. Brosius

Kowalczyk MS, Higgs DR, Gingeras TR. 2012. Molecular biology: RNA discrimination. Nature 482: 310-311.

Kriegs JO, Schmitz J, Makalowski W, Brosius J. 2005. Does the AD7c-NTP locus encode a protein? Biochim Biophys Acta 1727: 1-4.

Kruger K, Grabowski PJ, Zaug AJ, Sands J, Gottschling DE, Cech TR. 1982. Self-splicing RNA: Autoexcision and autocyclization of the ribosomal RNA intervening sequence of Tetrahymena. Cell 31: 147-157.

Krull M, Brosius J, Schmitz J. 2005. Alu-SINE exonization: En route to protein-coding function. Mol Biol Evol 22: 1702-1711.

Krull M, Petrusma M, Makalowski W, Brosius J, Schmitz J. 2007. Functional persistence of exonized mammalianwide interspersed repeat elements (MIRs). Genome Res 17: 1139-1145.

Kung JT, Colognori D, Lee JT. 2013. Long noncoding RNAs: Past, present, and future. Genetics 193: 651-669.

Lagos-Quintana M, Rauhut R, Lendeckel W, Tuschl T. 2001. Identification of novel genes coding for small expressed RNAs. Science 294: 853-858.

Lambowitz AM, Zimmerly S. 2011. Group II introns: Mobile ribozymes that invade DNA. Cold Spring Harb Perspect Biol 3: a003616.

Lau NC, Lim LP, Weinstein EG, Bartel DP. 2001. An abundant class of tiny RNAs with probable regulatory roles in Caenorhabditis elegans. Science 294: 858-862.

Lee CA, Fournier MJ, Beckwith J. 1985. Escherichia coli $6 S$ RNA is not essential for growth or protein secretion. $J$ Bacteriol 161: 1156-1161.

Lee YS, Shibata Y, Malhotra A, Dutta A. 2009. A novel class of small RNAs: tRNA-derived RNA fragments (tRFs). Genes Dev 23: 2639-2649.

Lerner MR, Boyle JA, Mount SM, Wolin SL, Steitz JA. 1980. Are snRNPs involved in splicing? Nature 283: 220-224.

Leslie M. 2013a. Cell Biology. NIH effort gambles on mysterious extracellular RNAs. Science 341: 947.

Leslie M. 2013b. Cell biology. The immune system's compact genomic counterpart. Science 339: 25-27.

Lev-Maor G, Sorek R, Shomron N, Ast G. 2003. The birth of an alternatively spliced exon: $3^{\prime}$ splice-site selection in Alu exons. Science 300: 1288-1291.

Lewejohann L, Skryabin BV, Sachser N, Prehn C, Heiduschka P, Thanos S, Jordan U, Dell'Omo G, Vyssotski AL, Pleskacheva MG, et al. 2004. Role of a neuronal small non-messenger RNA: Behavioural alterations in $\mathrm{BCl}$ RNA-deleted mice. Behav Brain Res 154: 273-289.

Lewis EB. 1951. Pseudoallelism and gene evolution. Cold Spring Harb Symp Quant Biol 16: 159-174.

Li HD, Zagorski J, Fournier MJ. 1990. Depletion of U14 small nuclear RNA (snR128) disrupts production of 18S rRNA in Saccharomyces cerevisiae. Mol Cell Biol 10: $1145-1152$.

Li L, Liu B, Wapinski OL, Tsai MC, Qu K, Zhang J, Carlson JC, Lin M, Fang F, Gupta RA, et al. 2013. Targeted disruption of Hotair leads to homeotic transformation and gene derepression. Cell Rep 5: 3-12.

Liang KH, Yeh CT. 2013. A gene expression restriction network mediated by sense and antisense Alu sequences located on protein-coding messenger RNAs. BMC Genomics 14: 325 .

Lincoln TA, Joyce GF. 2009. Self-sustained replication of an RNA enzyme. Science 323: 1229-1232.

Lindblad-Toh K, Garber M, Zuk O, Lin MF, Parker BJ, Washietl S, Kheradpour P, Ernst J, Jordan G, Mauceli E, et al. 2011. A high-resolution map of human evolutionary constraint using 29 mammals. Nature 478: 476-482.

Long M, Betran E, Thornton K, Wang W. 2003. The origin of new genes: Glimpses from the young and old. Nat Rev Genet 4: 865-875.

Long M, VanKuren NW, Chen S, Vibranowski MD. 2013. New gene evolution: Little did we know. Annu Rev Genet 47: 307-333.

Lowe CB, Haussler D. 2012. 29 mammalian genomes reveal novel exaptations of mobile elements for likely regulatory functions in the human genome. PloS ONE 7: e43128.

Lunyak VV, Prefontaine GG, Nunez E, Cramer T, Ju BG, Ohgi KA, Hutt K, Roy R, Garcia-Diaz A, Zhu X, et al. 2007. Developmentally regulated activation of a SINE B2 repeat as a domain boundary in organogenesis. Science 317: $248-251$.

Lynch M, Force A. 2000. The probability of duplicate gene preservation by subfunctionalization. Genetics 154: 459-473.

Lynch VJ, Leclerc RD, May G, Wagner GP. 2011. Transposon-mediated rewiring of gene regulatory networks contributed to the evolution of pregnancy in mammals. Nat Genet 43: 1154-1159.

Magny EG, Pueyo JI, Pearl FM, Cespedes MA, Niven JE, Bishop SA, Couso JP. 2013. Conserved regulation of cardiac calcium uptake by peptides encoded in small open reading frames. Science 341: 1116-1120.

Maizels N, Weiner AM. 1987. Peptide-specific ribosomes, genomic tags, and the origin of the genetic code. Cold Spring Harb Symp Quant Biol 52: 743-749.

Makalowski W, Mitchell GA, Labuda D. 1994. Alu sequences in the coding regions of mRNA: A source of protein variability. Trends Genet 10: 188-193.

Managadze D, Lobkovsky AE, Wolf YI, Shabalina SA, Rogozin IB, Koonin EV. 2013. The vast, conserved mammalian lincRNome. PLoS Comput Biol 9: e1002917.

Mandal AK, Pandey R, Jha V, Mukerji M. 2013. Transcriptome-wide expansion of non-coding regulatory switches: Evidence from co-occurrence of Alu exonization, antisense and editing. Nucleic Acids Res 41: 2121-2137.

Mansy SS, Schrum JP, Krishnamurthy M, Tobe S, Treco DA, Szostak JW. 2008. Template-directed synthesis of a genetic polymer in a model protocell. Nature 454: 122-125.

Marahrens Y, Panning B, Dausman J, Strauss W, Jaenisch R. 1997. Xist-deficient mice are defective in dosage compensation but not spermatogenesis. Genes Dev 11: 156-166.

Mariner PD, Walters RD, Espinoza CA, Drullinger LF, Wagner SD, Kugel JF, Goodrich JA. 2008. Human Alu RNA is a modular transacting repressor of mRNA transcription during heat shock. Mol Cell 29: 499-509.

Marques AC, Ponting CP. 2009. Catalogues of mammalian long noncoding RNAs: Modest conservation and incompleteness. Genome Biol 10: R124. 
Martens JA, Laprade L, Winston F. 2004. Intergenic transcription is required to repress the Saccharomyces cerevisiae SER3 gene. Nature 429: 571-574.

Martignetti JA, Brosius J. 1993. Neural BC1 RNA as an evolutionary marker: Guinea pig remains a rodent. Proc Natl Acad Sci 90: 9698-9702.

Martin W, Koonin EV. 2006. Introns and the origin of nucleus-cytosol compartmentalization. Nature 440: 41-45.

Mast CB, Schink S, Gerland U, Braun D. 2013. Escalation of polymerization in a thermal gradient. Proc Natl Acad Sci 110: $8030-8035$.

Mattick JS. 1994. Introns: Evolution and function. Curr Opin Genet Dev 4: 823-831.

Mattick JS. 2003. Challenging the dogma: The hidden layer of non-protein-coding RNAs in complex organisms. BioEssays 25: 930-939.

Mattick JS, Dinger ME. 2013. The extent of functionality in the human genome. HUGO J 7: 2

Maynard Smith J, Szathmáry E. 1995. The major transitions in evolution. Oxford University Press, Oxford.

McKinnon RD, Shinnick TM, Sutcliffe JG. 1986. The neuronal identifier element is a cis-acting positive regulator of gene expression. Proc Natl Acad Sci 83: 3751-3755.

Medstrand P, van de Lagemaat LN, Dunn CA, Landry JR, Svenback D, Mager DL. 2005. Impact of transposable elements on the evolution of mammalian gene regulation. Cytogenet Genome Res 110: 342-352.

Memczak S, Jens M, Elefsinioti A, Torti F, Krueger J, Rybak A, Maier L, Mackowiak SD, Gregersen LH, Munschauer $\mathrm{M}$, et al. 2013. Circular RNAs are a large class of animal RNAs with regulatory potency. Nature 495: 333-338.

Mercer TR, Gerhardt DJ, Dinger ME, Crawford J, Trapnell C, Jeddeloh JA, Mattick JS, Rinn JL. 2012. Targeted RNA sequencing reveals the deep complexity of the human transcriptome. Nat Biotechnol 30: 99-104.

Milner RJ, Bloom FE, Lai C, Lerner RA, Sutcliffe JG. 1984. Brain-specific genes have identifier sequences in their introns. Proc Natl Acad Sci 81: 713-717.

Mo D, Raabe CA, Reinhardt R, Brosius J, Rozhdestvensky TS. 2013. Alternative processing as evolutionary mechanism for the origin of novel non-protein coding RNAs. Genome Biol Evol 5: 2061-2071.

Monte SM, Ghanbari K, Frey WH, Beheshti I, Averback P, Hauser SL, Ghanbari HA, Wands JR. 1997. Characterization of the AD7C-NTP cDNA expression in Alzheimer's disease and measurement of a $41-\mathrm{kD}$ protein in cerebrospinal fluid. J Clin Invest 100: 3093-3104.

Moss EG. 2001. RNA interference: It's a small RNA world. Curr Biol 11: R772-R775.

Mudge JM, Frankish A, Harrow J. 2013. Functional transcriptomics in the post-ENCODE era. Genome Res 23: 1961-1973.

Muller HJ. 1935. The origination of chromatin deficiencies as minute deletions subject to insertion elsewhere. Genetics 17: 237-252.

Muotri AR, Chu VT, Marchetto MC, Deng W, Moran JV, Gage FH. 2005. Somatic mosaicism in neuronal precursor cells mediated by L1 retrotransposition. Nature 435: 903-910.
RNA and Eukaryotic Gene/Genome Architecture

Murphy DN, McLysaght A. 2012. De novo origin of proteincoding genes in murine rodents. PloS ONE 7: e48650.

Necsulea A, Soumillon M, Warnefors M, Liechti A, Daish T, Zeller U, Baker JC, Grutzner F, Kaessmann H. 2014. The evolution of lncRNA repertoires and expression patterns in tetrapods. Nature 505: 635-640.

Nei M. 1969. Gene duplication and nucleotide substitution in evolution. Nature 221: 40-42.

Neil H, Malabat C, d'Aubenton-Carafa Y, Xu Z, Steinmetz LM, Jacquier A. 2009. Widespread bidirectional promoters are the major source of cryptic transcripts in yeast. Nature 457: 1038-1042.

Nekrutenko A, Li WH. 2001. Transposable elements are found in a large number of human protein-coding genes. Trends Genet 17: 619-621.

Nelson AC, Wardle FC. 2013. Conserved non-coding elements and cis regulation: Actions speak louder than words. Development 140: 1385-1395.

Neme R, Tautz D. 2013. Phylogenetic patterns of emergence of new genes support a model of frequent de novo evolution. BMC Genomics 14: 117.

Nesse RM, Ganten D, Gregory TR, Omenn GS. 2012. Evolutionary molecular medicine. J Mol Med (Berl) 90: 509522.

Neveu M, Kim HJ, Benner SA. 2013. The "strong" RNA world hypothesis: Fifty years old. Astrobiology 13: 391403.

Nielsen MM, Tehler D, Vang S, Sudzina F, Hedegaard J, Nordentoft I, Orntoft TF, Lund AH, Pedersen JS. 2014. Identification of expressed and conserved human noncoding RNAs. RNA 20: 236-251.

Nirenberg M, Leder P, Bernfield M, Brimacombe R, Trupin J, Rottman F, O'Neal C. 1965. RNA codewords and protein synthesis: VII. On the general nature of the RNA code. Proc Natl Acad Sci 53: 1161-1168.

Niu DK, Jiang L. 2013. Can ENCODE tell us how much junk DNAwe carry in our genome? Biochem Biophys Res Commun 430: 1340-1343.

Noller HF. 2012. Evolution of protein synthesis from an RNA world. Cold Spring Harb Perspect Biol 4: a003681.

Noller HF, Chaires JB. 1972. Functional modification of $16 \mathrm{~S}$ ribosomal RNA by kethoxal. Proc Natl Acad Sci 69:31153118.

Noller HF, Hoffarth V, Zimniak L. 1992. Unusual resistance of peptidyl transferase to protein extraction procedures. Science 256: 1416-1419.

Orgel LE. 1968. Evolution of the genetic apparatus. J Mol Biol 38: 381-393.

Orom UA, Shiekhattar R. 2013. Long noncoding RNAs usher in a new era in the biology of enhancers. Cell 154: 1190-1193.

Owens GP, Chaudhari N, Hahn WE. 1985. Brain "identifier sequence" is not restricted to brain: Similar abundance in nuclear RNA of other organs. Science 229: 1263-1265.

Parra G, Reymond A, Dabbouseh N, Dermitzakis ET, Castelo R, Thomson TM, Antonarakis SE, Guigo R. 2006. Tandem chimerism as a means to increase protein complexity in the human genome. Genome Res 16: 37-44.

Perrat PN, DasGupta S, Wang J, Theurkauf W, Weng Z, Rosbash M, Waddell S. 2013. Transposition-driven geno- 
J. Brosius

mic heterogeneity in the Drosophila brain. Science 340: 91-95.

Petherick A. 2008. Genetics: The production line. Nature 454: 1042-1045.

Pink RC, Wicks K, Caley DP, Punch EK, Jacobs L, Carter DR. 2011. Pseudogenes: Pseudo-functional or key regulators in health and disease? RNA 17: 792-798.

Polev D. 2012. Transcriptional noise as a driver of gene evolution. J Theor Biol 293: 27-33.

Poliseno L, Salmena L, Zhang J, Carver B, Haveman WJ, Pandolfi PP. 2010. A coding-independent function of gene and pseudogene mRNAs regulates tumour biology. Nature 465: 1033-1038.

Ponicsan SL, Houel S, Old WM, Ahn NG, Goodrich JA, Kugel JF. 2013. The non-coding B2 RNA binds to the DNA cleft and active-site region of RNA polymerase II. J Mol Biol 425: 3625-3638.

Ponting CP, Oliver PL, Reik W. 2009. Evolution and functions of long noncoding RNAs. Cell 136: 629-641.

Poole A, Jeffares D, Penny D. 1999. Early evolution: Prokaryotes, the new kids on the block. BioEssays 21: 880-889.

Powner MW, Gerland B, Sutherland JD. 2009. Synthesis of activated pyrimidine ribonucleotides in prebiotically plausible conditions. Nature 459: 239-242.

Prasanth KV, Spector DL. 2007. Eukaryotic regulatory RNAs: An answer to the "genome complexity" conundrum. Genes Dev 21: 11-42.

Prestayko AW, Busch H. 1968. Low molecular weight RNA of the chromatin fraction from Novikoff hepatoma and rat liver nuclei. Biochim Biophys Acta 169: 327-337.

Reanney DC. 1974. On the origin of prokaryotes. J Theor Biol 48: 243-251.

Rebollo R, Romanish MT, Mager DL. 2012. Transposable elements: An abundant and natural source of regulatory sequences for host genes. Annu Rev Genet 46: 21-42.

Reilly MT, Faulkner GJ, Dubnau J, Ponomarev I, Gage FH. 2013. The role of transposable elements in health and diseases of the central nervous system. J Neurosci 33: 17577-17586.

Rich A. 1962. On the problems of evolution and biochemical information transfer. In Horizons in biochemistry (ed. Kasha M, Pullman B), pp. 103-126. Academic, New York.

Richard P, Manley JL. 2009. Transcription termination by nuclear RNA polymerases. Genes Dev 23: 1247-1269.

Rinn JL, Kertesz M, Wang JK, Squazzo SL, Xu X, Brugmann SA, Goodnough LH, Helms JA, Farnham PJ, Segal E, et al. 2007. Functional demarcation of active and silent chromatin domains in human HOX loci by noncoding RNAs. Cell 129: 1311-1323.

Ritz K, van Schaik BD, Jakobs ME, Aronica E, Tijssen MA, van Kampen AH, Baas F. 2011. Looking ultra deep: Short identical sequences and transcriptional slippage. Genomics 98: 90-95.

Robertson MP, Joyce GF. 2012. The origins of the RNA world. Cold Spring Harb Perspect Biol 4: a003608.

Robinson R. 2010. Dark matter transcripts: Sound and fury, signifying nothing? PLoS Biol 8: e1000370.

Ross RJ, Weiner MM, Lin H. 2014. PIWI proteins and PIWIinteracting RNAs in the soma. Nature 505: 353-359.
Roth C, Rastogi S, Arvestad L, Dittmar K, Light S, Ekman D, Liberles DA. 2007. Evolution after gene duplication: Models, mechanisms, sequences, systems, and organisms. J Exp Zool B Mol Dev Evol 308: 58-73.

Rudd KE, Humphery-Smith I, Wasinger VC, Bairoch A. 1998. Low molecular weight proteins: A challenge for post-genomic research. Electrophoresis 19: 536-544.

Runte M, Huttenhofer A, Gross S, Kiefmann M, Horsthemke B, Buiting K. 2001. The IC-SNURF-SNRPN transcript serves as a host for multiple small nucleolar RNA species and as an antisense RNA for UBE3A. Hum Mol Genet 10: 2687-2700.

Ruvkun G. 2001. Molecular biology. Glimpses of a tiny RNA world. Science 294: 797-799.

Sabin LR, Delas MJ, Hannon GJ. 2013. Dogma derailed: The many influences of RNA on the genome. Mol Cell 49: 783-794.

Sacerdote MG, Szostak JW. 2005. Semipermeable lipid bilayers exhibit diastereoselectivity favoring ribose. Proc Natl Acad Sci 102: 6004-6008.

Salzman J, Gawad C, Wang PL, Lacayo N, Brown PO. 2012. Circular RNAs are the predominant transcript isoform from hundreds of human genes in diverse cell types. PloS ONE 7: e30733.

Santangelo AM, de Souza FS, Franchini LF, Bumaschny VF, Low MJ, Rubinstein M. 2007. Ancient exaptation of a CORE-SINE retroposon into a highly conserved mammalian neuronal enhancer of the proopiomelanocortin gene. PLoS Genet 3: 1813-1826.

Sapienza C, St-Jacques B. 1986. "Brain- specific" transcription and evolution of the identifier sequence. Nature 319: $418-420$.

Sasaki T, Nishihara H, Hirakawa M, Fujimura K, Tanaka M, Kokubo N, Kimura-Yoshida C, Matsuo I, Sumiyama K, Saitou N, et al. 2008. Possible involvement of SINEs in mammalian-specific brain formation. Proc Natl Acad Sci 105: 4220-4225.

Sauvageau M, Goff LA, Lodato S, Bonev B, Groff AF, Gerhardinger C, Sanchez-Gomez DB, Hacisuleyman E, Li E, Spence M, et al. 2013. Multiple knockout mouse models reveal lincRNAs are required for life and brain development. eLife 2: e01749.

Savard J, Marques-Souza H, Aranda M, Tautz D. 2006. A segmentation gene in tribolium produces a polycistronic mRNA that codes for multiple conserved peptides. Cell 126: $559-569$.

Saxena A, Carninci P. 2011a. Long non-coding RNA modifies chromatin: Epigenetic silencing by long non-coding RNAs. BioEssays 33: 830-839.

Saxena A, Carninci P. 2011b. Whole transcriptome analysis: What are we still missing? Wiley Interdiscip Rev Syst Bio Med 3: 527-543.

Schartl M, Hornung U, Gutbrod H, Volff JN, Wittbrodt J. 1999. Melanoma loss-of-function mutants in Xiphophorus caused by Xmrk-oncogene deletion and gene disruption by a transposable element. Genetics 153: 1385-1394.

Schonberg DL, Bao S, Rich JN. 2013. Genomics informs glioblastoma biology. Nat Genet 45: 1105-1107.

Schöning K, Scholz P, Guntha S, Wu X, Krishnamurthy R, Eschenmoser A. 2000. Chemical etiology of nucleic acid 
structure: The $\alpha$-threofuranosyl- $\left(3^{\prime} \rightarrow 2^{\prime}\right)$ oligonucleotide system. Science 290: 1347-1351.

Schorderet P, Duboule D. 2011. Structural and functional differences in the long non-coding RNA hotair in mouse and human. PLoS Genet 7: e1002071.

Seila AC, Calabrese JM, Levine SS, Yeo GW, Rahl PB, Flynn RA, Young RA, Sharp PA. 2008. Divergent transcription from active promoters. Science 322: 1849-1851.

Sen K, Ghosh TC. 2013. Pseudogenes and their composers: Delving in the "debris" of human genome. Brief Funct Genomics 12: 536-547.

Shah SP, Roth A, Goya R, Oloumi A, Ha G, Zhao Y, Turashvili G, Ding J, Tse K, Haffari G, et al. 2012. The clonal and mutational evolution spectrum of primary triple-negative breast cancers. Nature 486: 395-399.

Sharp PA. 1991. Five easy pieces. Science 254: 663.

Shechner DM, Grant RA, Bagby SC, Koldobskaya Y, Piccirilli JA, Bartel DP. 2009. Crystal structure of the catalytic core of an RNA-polymerase ribozyme. Science 326: 12711275.

Shen S, Lin L, Cai JJ, Jiang P, Kenkel EJ, Stroik MR, Sato S, Davidson BL, Xing Y. 2011. Widespread establishment and regulatory impact of Alu exons in human genes. Proc Natl Acad Sci 108: 2837-2842.

Shen Y, Yue F, McCleary DF, Ye Z, Edsall L, Kuan S, Wagner U, Dixon J, Lee L, Lobanenkov VV, et al. 2012. A map of the cis-regulatory sequences in the mouse genome. $\mathrm{Na}$ ture 488: 116-120.

Sibilia M, Wagner EF. 1995. Strain-dependent epithelial defects in mice lacking the EGF receptor. Science 269: $234-$ 238.

Siepel A. 2009. Darwinian alchemy: Human genes from noncoding DNA. Genome Res 19: 1693-1695.

Singer T, McConnell MJ, Marchetto MC, Coufal NG, Gage FH. 2010. LINE-1 retrotransposons: Mediators of somatic variation in neuronal genomes? Trends Neurosci 33: 345-354.

Skryabin BV, Gubar LV, Seeger B, Pfeiffer J, Handel S, Robeck T, Karpova E, Rozhdestvensky TS, Brosius J. 2007. Deletion of the MBII-85 snoRNA gene cluster in mice results in postnatal growth retardation. PLoS Genet 3: e235.

Söll D, Ohtsuka E, Jones DS, Lohrmann R, Hayatsu H, Nishimura S, Khorana HG. 1965. Studies on polynucleotides, XLIX. Stimulation of the binding of aminoacylsRNA's to ribosomes by ribotrinucleotides and a survey of codon assignments for 20 amino acids. Proc Natl Acad Sci 54: 1378-1385.

Sorek R, Ast G, Graur D. 2002. Alu-containing exons are alternatively spliced. Genome Res 12: 1060-1067.

Sousa C, Johansson C, Charon C, Manyani H, Sautter C, Kondorosi A, Crespi M. 2001. Translational and structural requirements of the early nodulin gene enod 40 , a short-open reading frame-containing RNA, for elicitation of a cell-specific growth response in the alfalfa root cortex. Mol Cell Biol 21: 354-366.

Spengler RM, Oakley CK, Davidson BL. 2014. Functional microRNAs and target sites are created by lineage-specific transposition. Hum Mol Genet 23: 1783-1793.

Stephens SG. 1951. Possible significances of duplication in evolution. Adv Genet 4: 247-265.
RNA and Eukaryotic Gene/Genome Architecture

St Laurent G, Shtokalo D, Tackett MR, Yang Z, Eremina T, Wahlestedt C, Urcuqui-Inchima S, Seilheimer B, McCaffrey TA, Kapranov P. 2012. Intronic RNAs constitute the major fraction of the non-coding RNA in mammalian cells. BMC Genomics 13: 504.

Struhl K. 2007. Transcriptional noise and the fidelity of initiation by RNA polymerase II. Nat Struct Mol Biol 14: 103-105.

Sutcliffe JG, Milner RJ, Gottesfeld JM, Lerner RA. 1984a. Identifier sequences are transcribed specifically in brain. Nature 308: 237-241.

Sutcliffe JG, Milner RJ, Gottesfeld JM, Reynolds W. 1984b. Control of neuronal gene expression. Science 225: 1308 1315.

Szathmáry E. 2006. The origin of replicators and reproducers. Philos Trans R Soc Lond B Biol Sci 361: 1761-1776.

Szathmáry E, Smith JM. 1995. The major evolutionary transitions. Nature 374: 227-232.

Szostak JW, Bartel DP, Luisi PL. 2001. Synthesizing life. Nature 409: 387-390.

Takeuchi N, Hogeweg P. 2008. Evolution of complexity in RNA-like replicator systems. Biol Direct 3: 11.

Taleb NN. 2010. The bed of Procrustes: Philosophical and practical aphorisms. Random House, New York.

Tay Y, Rinn J, Pandolfi PP. 2014. The multilayered complexity of ceRNA crosstalk and competition. Nature 505: 344-352.

Taylor DJ, Bruenn J. 2009. The evolution of novel fungal genes from non-retroviral RNA viruses. BMC Biol 7: 88.

Thompson JR, Zagorski J, Woolford JL, Fournier MJ. 1988. Sequence and genetic analysis of a dispensible 189 nucleotide snRNA from Saccharomyces cerevisiae. Nucleic Acids Res 16: $5587-5601$.

Tiedge H, Fremeau RT Jr, Weinstock PH, Arancio O, Brosius J. 1991. Dendritic location of neural BC1 RNA. Proc Natl Acad Sci 88: 2093-2097.

Tisseur M, Kwapisz M, Morillon A. 2011. Pervasive transcription-Lessons from yeast. Biochimie 93: 1889-1896.

Trifonov EN. 1989. The multiple codes of nucleotide sequences. Bull Math Biol 51: 417-432.

Trotochaud AE, Wassarman KM. 2004. 6S RNA function enhances long-term cell survival. J Bacteriol 186: 49784985.

Tuerk C, Gold L. 1990. Systematic evolution of ligands by exponential enrichment: RNA ligands to bacteriophage T4 DNA polymerase. Science 249: 505-510.

Uesaka M, Nishimura O, Go Y, Nakashima K, Agata K, Imamura T. 2014. Bidirectional promoters are the major source of gene activation-associated non-coding RNAs in mammals. BMC Genomics 15: 35.

Uhler JP, Hertel C, Svejstrup JQ. 2007. A role for noncoding transcription in activation of the yeast $\mathrm{PHO}$ gene. Proc Natl Acad Sci 104: 8011-8016.

Ulitsky I, Bartel DP. 2013. lincRNAs: Genomics, evolution, and mechanisms. Cell 154: 26-46.

Upton KR, Baillie JK, Faulkner GJ. 2011. Is somatic retrotransposition a parasitic or symbiotic phenomenon? Mob Genet Elements 1: 279-282. 
Vaidya N, Manapat ML, Chen IA, Xulvi-Brunet R, Hayden EJ, Lehman N. 2012. Spontaneous network formation among cooperative RNA replicators. Nature 491: 72-77.

van Bakel H, Nislow C, Blencowe BJ, Hughes TR. 2010. Most "dark matter" transcripts are associated with known genes. PLoS Biol 8: el000371.

van de Lagemaat LN, Landry JR, Mager DL, Medstrand P. 2003. Transposable elements in mammals promote regulatory variation and diversification of genes with specialized functions. Trends Genet 19: 530-536.

van der Veen R, Arnberg AC, van der Horst G, Bonen L, Tabak HF, Grivell LA. 1986. Excised group II introns in yeast mitochondria are lariats and can be formed by selfsplicing in vitro. Cell 44: 225-234.

van Heesch S, van Iterson M, Jacobi J, Boymans S, Essers PB, de Bruijn E, Hao W, Macinnes AW, Cuppen E, Simonis M. 2014. Extensive localization of long noncoding RNAs to the cytosol and mono- and polyribosomal complexes. Genome Biol 15: R6.

Volff JN. 2006. Turning junk into gold: Domestication of transposable elements and the creation of new genes in eukaryotes. BioEssays 28: 913-922.

Volff JN. 2009. Cellular genes derived from Gypsy/Ty3 retrotransposons in mammalian genomes. Ann NY Acad Sci 1178: $233-243$.

Wang H, Iacoangeli A, Popp S, Muslimov IA, Imataka H, Sonenberg N, Lomakin IB, Tiedge H. 2002. Dendritic BC1 RNA: Functional role in regulation of translation initiation. J Neurosci 22: 10232-10241.

Wang T, Zeng J, Lowe CB, Sellers RG, Salama SR, Yang M, Burgess SM, Brachmann RK, Haussler D. 2007. Speciesspecific endogenous retroviruses shape the transcriptional network of the human tumor suppressor protein $\mathrm{p} 53$. Proc Natl Acad Sci 104: 18613-18618.

Wang Z, Gerstein M, Snyder M. 2009. RNA-Seq: A revolutionary tool for transcriptomics. Nat Rev Genet 10: 57-63.

Wang J, Gong C, Maquat LE. 2013. Control of myogenesis by rodent SINE-containing lncRNAs. Genes Dev 27: 793-804.

Ward LD, Kellis M. 2012. Evidence of abundant purifying selection in humans for recently acquired regulatory functions. Science 337: 1675-1678.

Washietl S, Pedersen JS, Korbel JO, Stocsits C, Gruber AR, Hackermuller J, Hertel J, Lindemeyer M, Reiche K, Tanzer A, et al. 2007. Structured RNAs in the ENCODE selected regions of the human genome. Genome Res 17: 852-864.

Wassarman KM, Storz G. 2000. 6S RNA regulates E. coli RNA polymerase activity. Cell 101: 613-623.

Watanabe Y, Yamamoto M. 1994. S. pombe mei $2^{+}$encodes an RNA-binding protein essential for premeiotic DNA synthesis and meiosis I, which cooperates with a novel RNA species meiRNA. Cell 78: 487-498.

Wei W, Pelechano V, Jarvelin AI, Steinmetz LM. 2011. Functional consequences of bidirectional promoters. Trends Genet 27: 267-276.

Weiner AM. 2006. SINEs and LINEs: Troublemakers, saboteurs, benefactors, ancestors. In The RNA world (ed. Gesteland RF, Cech TR, Atkins JF), pp. 507-533. Cold Spring Harbor Laboratory Press, Cold Spring Harbor, NY.
Wen YZ, Zheng LL, Qu LH, Ayala FJ, Lun ZR. 2012. Pseudogenes are not pseudo any more. RNA Biol 9: 27-32.

Williams GC, Nesse RM. 1991. The dawn of Darwinian medicine. Q Rev Biol 66: 1-22.

Wochner A, Attwater J, Coulson A, Holliger P. 2011. Ribozyme-catalyzed transcription of an active ribozyme. Science 332: 209-212.

Woese CR. 1967. The genetic code: The molecular basis for genetic expression. Harper and Row, New York.

Woese CR. 1979. A proposal concerning the origin of life on the planet earth. J Mol Evol 13: 95-101.

Wu X, Weigel D, Wigge PA. 2002. Signaling in plants by intercellular RNA and protein movement. Genes Dev 16: $151-158$.

Xie D, Chen CC, Ptaszek LM, Xiao S, Cao X, Fang F, Ng HH, Lewin HA, Cowan C, Zhong S. 2010. Rewirable gene regulatory networks in the preimplantation embryonic development of three mammalian species. Genome Res 20: 804-815.

Xiong Y, Eickbush TH. 1990. Origin and evolution of retroelements based upon their reverse transcriptase sequences. EMBO J 9: 3353-3362.

Xu Z, Wei W, Gagneur J, Perocchi F, Clauder-Munster S, Camblong J, Guffanti E, Stutz F, Huber W, Steinmetz LM. 2009. Bidirectional promoters generate pervasive transcription in yeast. Nature 457: 1033-1037.

Yakovchuk P, Goodrich JA, Kugel JF. 2011. B2 RNA represses TFIIH phosphorylation of RNA polymerase II. Transcription 2: 45-49.

Yang L, Froberg JE, Lee JT. 2014. Long noncoding RNAs: Fresh perspectives into the RNA world. Trends Biochem Sci 39: 35-43.

Yarus M. 2011. Getting past the RNA world: The initial Darwinian ancestor. Cold Spring Harb Perspect Biol 3: a003590.

Yin QF, Yang L, Zhang Y, Xiang JF, Wu YW, Carmichael GG, Chen LL. 2012. Long noncoding RNAs with snoRNA ends. Mol Cell 48: 219-230.

Yoshihara K, Shahmoradgoli M, Martinez E, Vegesna R, Kim H, Torres-Garcia W, Trevino V, Shen H, Laird PW, Levine DA, et al. 2013. Inferring tumour purity and stromal and immune cell admixture from expression data. Nature Comm 4: 2612.

Zaher HS, Unrau PJ. 2007. Selection of an improved RNA polymerase ribozyme with superior extension and fidelity. RNA 13: 1017-1026.

Zhang L, Peritz A, Meggers E. 2005. A simple glycol nucleic acid. J Am Chem Soc 127: 4174-4175.

Zhernakova DV, de Klerk E, Westra HJ, Mastrokolias A, Amini S, Ariyurek Y, Jansen R, Penninx BW, Hottenga JJ, Willemsen G, et al. 2013. DeepSAGE reveals genetic variants associated with alternative polyadenylation and expression of coding and non-coding transcripts. PLoS Genet 9: e1003594.

Zieve G, Penman S. 1976. Small RNA species of the HeLa cell: Metabolism and subcellular localization. Cell 8: $19-31$. 


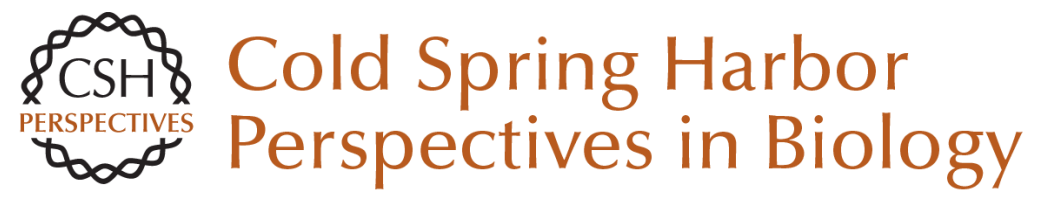

\section{The Persistent Contributions of RNA to Eukaryotic Gen(om)e Architecture and Cellular Function}

Jürgen Brosius

Cold Spring Harb Perspect Biol 2014; doi: 10.1101/cshperspect.a016089 originally published online July 31, 2014

Subject Collection The Origin and Evolution of Eukaryotes

The Persistent Contributions of RNA to

Eukaryotic Gen(om)e Architecture and Cellular

Function

Jürgen Brosius

Green Algae and the Origins of Multicellularity in the Plant Kingdom James $G$. Umen

The Archaeal Legacy of Eukaryotes: A

Phylogenomic Perspective

Lionel Guy, Jimmy H. Saw and Thijs J.G. Ettema

Origin and Evolution of the Self-Organizing

Cytoskeleton in the Network of Eukaryotic

\section{Organelles}

Gáspár Jékely

On the Age of Eukaryotes: Evaluating Evidence from Fossils and Molecular Clocks

Laura Eme, Susan C. Sharpe, Matthew W. Brown, et al.

Origin of Spliceosomal Introns and Alternative

Splicing

Manuel Irimia and Scott William Roy
Eukaryotic Origins: How and When Was the

Mitochondrion Acquired?

Anthony M. Poole and Simonetta Gribaldo

Bacterial Influences on Animal Origins

Rosanna A. Alegado and Nicole King

Missing Pieces of an Ancient Puzzle: Evolution of the Eukaryotic Membrane-Trafficking System Alexander Schlacht, Emily K. Herman, Mary J. Klute, et al.

The Neomuran Revolution and Phagotrophic Origin of Eukaryotes and Cilia in the Light of Intracellular Coevolution and a Revised Tree of Life

Thomas Cavalier-Smith

Protein Targeting and Transport as a Necessary

Consequence of Increased Cellular Complexity

Maik S. Sommer and Enrico Schleiff

How Natural a Kind Is "Eukaryote?"

W. Ford Doolittle

For additional articles in this collection, see http://cshperspectives.cshlp.org/cgi/collection/

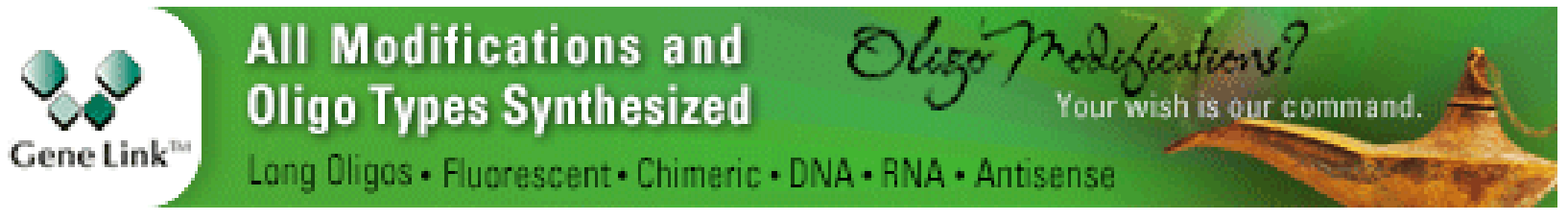

Copyright (C) 2014 Cold Spring Harbor Laboratory Press; all rights reserved 
Protein and DNA Modifications: Evolutionary Imprints of Bacterial Biochemical Diversification and Geochemistry on the Provenance of Eukaryotic Epigenetics

L. Aravind, A. Maxwell Burroughs, Dapeng Zhang, et al.

The Eukaryotic Tree of Life from a Global Phylogenomic Perspective Fabien Burki
What Was the Real Contribution of

Endosymbionts to the Eukaryotic Nucleus?

Insights from Photosynthetic Eukaryotes David Moreira and Philippe Deschamps

Bioenergetic Constraints on the Evolution of Complex Life

Nick Lane

For additional articles in this collection, see http://cshperspectives.cshlp.org/cgi/collection/

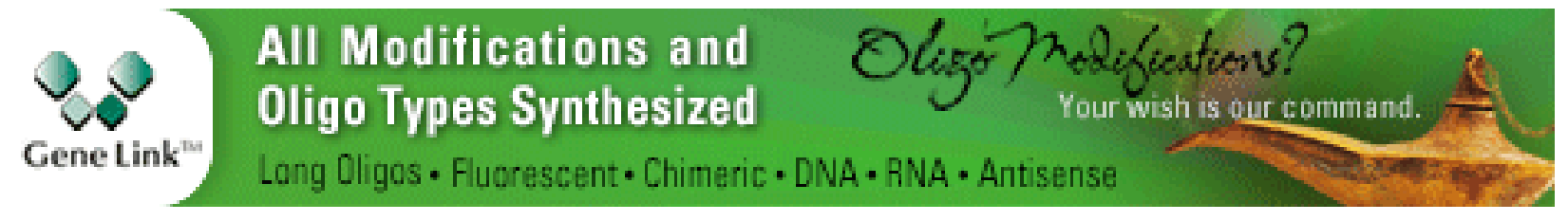

Copyright @ 2014 Cold Spring Harbor Laboratory Press; all rights reserved 